\title{
Evolution of Altruistic Motive and Crowding-out Effect in Turkey: Does Private Housing Support Matter?
}

\author{
Selin PELEK ${ }^{1} \odot$, Sezgin POLAT ${ }^{2} \odot$
}

\begin{abstract}
This paper aims to contribute to the growing literature on crowding out/in effects of public transfers in Turkey. We estimate the effects of public transfers on the amount and likelihood of receiving private transfers. We find that individual-level public transfers lead to crowding out whereas public transfers targeting households have no significant neutralizing effect. Comparing consecutive periods, the effect of altruistic motivation and crowding out are both decreasing. The broadly defined private transfers including housing support have a downstream character, are less altruistically motivated and produce less crowding out than with the narrow definition. This study has several policy implications: (i) public transfers for families excluded from social security coverage should be increased; (ii) public transfers targeting households should be strengthened; (iii) lone parents, particularly female-headed households should be prioritized; (iv) social welfare policy needs to complement private solidarity channels as the family structure and income composition of households change.
\end{abstract}

Keywords: Private transfers; public transfers; crowding out; altruism; housing support

\section{INTRODUCTION}

Turkey is one of the less egalitarian OECD countries, with a Gini coefficient of around 0.40 while, according to Eurostat, its income quintile share ratio (S80/S20) of 8.2 is the highest of European countries. Public transfers appear to have a small impact on Turkey's Gini coefficient for disposable income. According to OECD statistics the inclusion of public transfers reduces Gini coefficent only from 0.429 to 0.404 for the year of 2015. This indicates that the public transfers are inadequate and poorly targeted to reduce inequality. Turkey is not an exception in this since public transfers have a much shorter and more limited history in many developing countries than developed ones (Jensen, 2004). Social safety nets and inter-household transfers are supposed to act as a primary income buffer when social policy coverage is weak or public insufficiently supports needy families. As numerous studies show, particularly in developing countries, private income transfers constitute a significant share of household income (Maitra and Ray, 2003; Cox et al., 1998). World Bank, discusses broadly the role of informal support delivered by the family and community in alleviating poverty among elderly people (Holzmann and Hinz, 2005).

Along with high and persistent inequality, developing countries have witnessed several important structural changes in household characteristics, such as a transition to nuclear families, an increasing tendency to live alone and rising wage dependency, which make inter-household transfers more important for redistribution. In particular, many households receive private transfers from other households while private transfers significantly contribute to disposable income (Cox and Jimenez, 1990; Subbarao et al., 1997). Different types of households benefit from inter-vivos transfers, such as those with members employed in the traditional rural sector and/or modern sectors. For instance, parents commonly support their children living away from home or depend on transfers from their children to compensate for poor social security coverage.

A critical factor affecting these private transfer behaviors is the receiver's pre-transfer income. Theoretically, analyzing the motives for private transfers can help 
understand how responsive they are to redistribution. Becker (1974) and Barro (1974) emphasize altruistic motives for private transfers in discussing re-distributive neutrality. The mechanism in this context is straightforward: the likelihood of receiving private transfers is negatively correlated with the recipient's income. Thus, increasing public transfers as a component of income could reduce private transfers. In other words, crowding out neutralizes the re-distributive impact of public transfers. Alternatively, Bernheim et al. (1985) and Cox (1987) argue that transfer behavior can be better explained by the exchange motive. Here, income and private transfers are positively correlated due to a higher implicit price of services. In other words, private transfers increase with income and/or public transfers rather than decrease.

The interaction between public and private transfers is of particular importance for safety net design and public policy evaluation due to their re-distributive effects (Kananurak and Sirisankanan, 2016). With respect to pension system design, World Bank points to the expansion of three pillar model to a multi-pillared approach. This multipillar scheme includes a noncontributory or "zero pillar" that provides a minimal level of protection and intrafamily or intergenerational sources of both financial and nonfinancial support to the elderly. (Holzmann and Hinz, 2005; Holzmann et al., 2008) '. If public transfers tend to crowd out private transfers then it will be harder to alleviate poverty in the long term (Subbarao et al., 1997). Thus, the developing country context is particularly relevant for understanding transfer derivatives. Yet, although income transfers have received attention in terms of their re-distributive efficiency, few studies have focused on the public/private distinction in transfers or thoroughly investigated their interaction by focusing specifically on developing countries. However, as pointed out by Cox et al. (2004) and Nikolov and Bonci (2020), these countries generally provide less generous public transfers, which could provide better insight regarding crowding out (or in) effects.

Accordingly, this paper contributes to the literature by defining income transfers more broadly, by including private housing support (subsidized rents) and by empirically examining the relationship between public and private transfers in a developing country context using panel data. Our study is one of the few studies using such data over a relatively long period (four years) for a developing country like Turkey. Observing individuals in this way helps to address the endogeneity problem cited in the literature (Kang and Lee, 2003). We alter the definition of private transfers to include private housing support (subsidized rents), which is generally neglected in the literature. One novelty of this paper is to contrast transfer motives using both (narrow and broad) definitions of private transfers. Moreover, we contribute to the literature by differentiating public transfers according to their recipient unit, i.e. individual versus household level.

Our results indicate that individual-level public transfers significantly affect private ones whereas household-level public transfers do not play a key role. These results support the theory of altruistic behavior that individual-level public transfers crowd out private transfers in all specifications. Moreover, there is a gender-specific exchange motive at work for female recipients. Given the changing composition of transfer recipients by household type and the increasing size of private transfers in parallel with the pre-transfer income of lone-parent households, this outcome makes sense and contributes to the literature on developing countries. We also find a clear negative slope in transfer/ income ratios by income percentiles, which indicates that poorer households have higher private transfer ratios. Finally, the relationship between public transfers and income percentiles indicates that social policy in Turkey is insufficiently supporting poorer households.

Our study has several policy implications. First, public transfers modify inter-household transfers through the re-distributive channel. However, it is uncertain whether private transfers can re-balance redistribution if certain households no longer receive public transfers. In other words, the inter-household channel works through social interactions that may not be restored once dissolved. Government must therefore progressively increase its coverage of public transfers and complement private solidarity as a welfare provider. Moreover, private transfers are unstable as they depend on the donors' income streams. Consequently, relying on private solidarity is neither a sufficient nor sustainable way to cover social risks and help needy households cope with unexpected income shocks. We believe that weakening the private solidarity channel has broad implications for social policy in Turkey.

Our findings also suggest that gender should be prioritized by policy makers. Since female-headed households are significantly dependent on private transfers, public transfers must target households with lone parents, particularly female household heads with weak labor market attachment. Housing transfers could 
be one feasible option. ${ }^{2}$ Another issue is the low level of public transfers targeting households. Our results reveal that this type of family transfer is so insufficient that they do not crowd out private transfers. That is, receiving family transfers has no effect on the likelihood of receiving private transfers. We conclude that large-scale family and housing transfers are required in Turkey to support lower income families.

The rest of the paper is organized as follows. Section 2 presents a general overview of the literature. Section 3 briefly presents the data and descriptive statistics. Section 4 presents our empirical strategy. Sections 5 and 6 discuss our findings and conclude.

\section{LITERATURE REVIEW}

The empirical literature on inter-household transfers mainly examines two basic theoretical predictions. First one dates back to Becker (1974)'s family model which assumes the family as a re-distributive unit. Altruistic parents by transferring some of their income to their children increase their consumption. If private transfers decrease with pre-transfer income, then it is assumed that transfers are altruistically motived. Interestingly, Cox (1987) argues that private transfers might also be positively correlated with the income of recipient if there is some non-market services exchange (time spent with parents) is in play. In order to sustain the interaction (non-market exchange) between both parties, private transfers could increase with recipient's income. Second prediction is related to the interaction between public and private transfers. According to theoretical model first developed by Becker (1974), any increase in the income of the recipient should be matched with less private transfers. This model implies that public transfers could be neutralized bu altruistically motivated private transfers. If the public transfers are the source of the increase, then there is a crowding-out effect channel implying that the private redistribution is offset through public transfers. Motives for private income transfers are crucial to understand the effects of the public transfers on the private ones. The previous literature focuses mainly on two motives: altruism and exchange (Arrondel and Masson, 2006). Altruistic motive means that family members sufficiently care the well-being of each other and provide monetary support to increase one of its member's welfare if needed. In terms of utility, the welfare of an individual family member, is linked to the utility level of another member of the family. In other words, family acts as a unit of redistribution to increase consumption of its members through transfers. The family member with lowest income would receive more altruistic transfer from others, since marginal welfare gain would be greater for all family members. Exchange motive indicates that inter vivos private transfers are subject to an implicit contract between recipients and donors. The transfers correspond to some services provided by recipients such as elderly care and expected to be mutually advantegous (Arrondel and Masson, 2006).

Earlier evidence from developed countries indicates that altruism fails to explain the incentives for private transfers (Cox et al., 2004; Kunemund and Rein, 1999). After testing these two theories with US data, Cox (1987) and Cox and Rank (1992) conclude that inter vivos transfers are more consistent with the exchange motive than altruism. Cox and Jakubson (1995) estimate that a dollar increase in US public welfare spending would decrease private transfers by 12 cents at most.

Using French data, Attias-Donfut and Wolff (2000) find a mixed relationship between public and private transfers, with a positive correlation between receiving public transfers and the probability of receiving private transfers from parents. However, their simulations indicate that a 10-percent reduction in retirement pensions would decrease transfers from parents to children. Reil-Held (2006) examined the relationship between private and public financial transfers to and from elderly people in Germany. His results support the exchange motive and indicate that public transfers increase private ones from older to younger generations. Conversely, public transfers significantly reduce the probability of elderly people receiving private financial support. Kunemund and Rein (1999) find crowding in effects of public transfers in five developed countries Canada, Japan, UK, Germany and US.

Evidence from developing countries diverges significantly from developed countries since public welfare coverage in the latter is limited while re-distributive transfers are not sufficient to reduce inequality. Consequently, private redistribution mechanisms may dominate public ones, such as in the Philippines and Vietnam, where aggregate private transfers exceed public ones (Cox et al., 2006). Numerous studies on low and middle income countries document that the elderly commonly have informal private (family) insurance. Focusing on the correlation between social security benefits and private transfers in Peru, Cox and Jimenez (1992) conclude that private transfers from younger to older generations would be one fifth higher without social security benefits. Using an IV approach, Juarez 
(2009) reports significant crowding out from Mexico's re-distributive policy on private transfers to the elderly. Similarly, Jensen (2004) finds significant crowding out of private transfers in South Africa's old age pension system. On average, every rand increase in household pension income reduces private transfers from children by $0.25-0.30$ rand. In South Korea and Taiwan, where public transfers to support families have recently increased, Kim and Choi (2011) find that private transfers remain more effective reducers of inequality than public transfers. Regarding pension reform in Taiwan, Fan (2010) reports that each dollar of pensions crowds out 30-39 cents of private transfers to the elderly as well as reducing the probability that the recipients' children make transfers. Jung et al. (2016) report that extending Korea's public pension program has largely crowded out private transfers thereby leaving the elderly's consumption level unchanged. In China, pension benefits under a new program has made adult children less likely to transfer income to elderly parents (Nikolov and Adelman, 2019). Finally, from their comparative analysis of inter-household transfer in developing countries, Cox et al. (2006) conclude that countries with more extensive and generous public pensions tend to have less old-age support from private transfers.

Most studies of developing countries focus on the interaction between receivers' pre-transfer income and private transfers. Using Korean Household Panel Survey data for 1996-1998, Kang and Lee (2003) show that private transfers are altruistically motivated with a strong crowding out effect. In Nepal, private transfers seem to be altruistically motivated although, surprisingly, there seems to be no crowding out effect (Kang, 2004). From their evaluation of a randomized welfare program targeting the rural population, Albarran and Attanasio (2002) find that it significantly reduces both the likelihood of receiving a transfer and the amount received. Gerardi and Tsai (2014) confirm the crowding out hypothesis on the extensive margin of private transfers following the introduction of a new social security program in Taiwan. Using data from the Philippines, Cox et al. (2004) find that both the altruistic and exchange motive can explain different segments of the distribution in relation to the responsiveness of private transfers to prior transfer income. McKernan et al. (2005) find that gender plays a role in the relationship between formal and informal transfers in rural Bangladesh, specifically that men receive more money through transfers and credit than women. Regarding the gender-specific effects of credit programs, female program credit reduces credit and transfers received from relatives whereas male program credit increases credit and transfers sent to relatives (McKernan et al., 2005). Their regression results partially confirm that there is crowding out while transfers are altruistically motivated. Amuedo-Dorantes and Juarez (2015) report that a program for Mexico's rural elderly (at least 70 years old) crowds out total remittances by 37 percent. This effect is mostly driven by reducing the likelihood of receiving domestic remittances whereas the likelihood of international remittances is not significantly affected. Another striking finding is that overall crowding out is much greater for women than men. To sum up, the evidence from developing countries suggests that the altruistic motive is dominant and crowding out effects are not negligible.

The Turkish welfare system has expanded over the last decade in both amount and coverage (Buğra and Candas, 2011; Tekgüç, 2018). The amount of public transfers has increased throughout the analyzed period (Table 1), which makes Turkey an interesting case to explore the crowding out effect (Figure 1). The pattern regarding pre-transfer income by household type is more complex. Income levels of one-person households and households with dependent children decrease whereas they increase for households with no dependent children and one-parent households with dependent children. This trend remains unchanged when private housing support (imputed rent) is included in pre-transfer income. Consistent with demographic changes in Turkey, the wage/income ratio presented in Table 1 is rising. As in many other developing countries, the reliance on wage income increases with access to education which gives the younger generation greater social protection. One-person and one-parent households also have a low wage/income dependency ratio. This suggests that demographic characteristics may affect the nature of inter-household private transfers. For instance, younger generations may need more family support because their education takes longer. On the other hand, given a longer life expectancy and decreasing family size, the elderly may also need more care services.

There is increasing interest in documenting the characteristics of social assistance schemes in Turkey (Buğra and Adar, 2008; Baslevent, 2014; Tekgüç, 2018). Buğra and Keyder (2006) highlight the essential role of family-based support in risk situations along with the remarkable transformation in social assistance schemes within Turkey's neoliberal framework. Following Ferrera (1996), Kaya (2010) suggests that Turkey's welfare sys- 
tem matches the Southern European model in which private transfers based on family ties are not negligible and reduce the need for public transfers (Kaya, 2010). This point is crucial for our attempt to understand the interaction between public and private transfers. Turkey's welfare system is generally characterized as rudimentary with particularly low household benefits (Aybars and Tsarouhas, 2010; Gough, 1996; Grütjen, 2007). These ungenerous social assistance schemes leave room for alternative charitable bodies (Buğra and Candas, 2011) Although there are no micro-level data on the role of private or government-funded local charity organizations in welfare provision, it seems that traditional forms of welfare provision have been challenged during Turkey's era of single party government since 2002 (Pinarcioglu and Isik, 2009). However, to our knowledge, these interactions between public and private, i.e. inter-household transfers, have not been investigated yet in Turkey. Our paper is thus the first attempt to analyze the motives for private transfers and discuss the implications for Turkish public policy. We aim to contribute to the understanding of the relationship between public and private transfers, which is under-represented in the literature on Turkey.

5.00

4.50

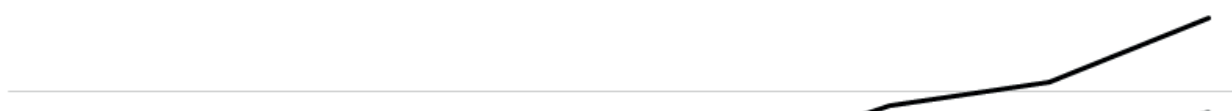

4.00

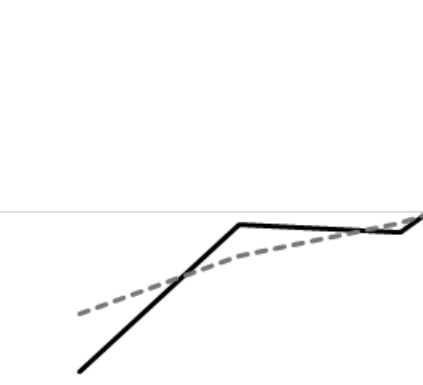
- - -

- Net social protection expenditures (2015 prices, thousand TL) / Working population (+15)

--- Number of benefits and pension beneficiaries as a $\%$ of working population $(+15$, right scale)

3.00

$\begin{array}{lllllll}2008 & 2009 & 2010 & 2011 & 2012 & 2013 & 2014\end{array}$

$16 \%$

Source: TurkStat, Social Protection Statistics. https://data.tuik.gov.tr/Kategori/GetKategori?p=Saglik-ve-Sosyal-Koruma-101

Figure 1: Evolution of social protection spending and coverage of benefit and pension system (2008-2015) 


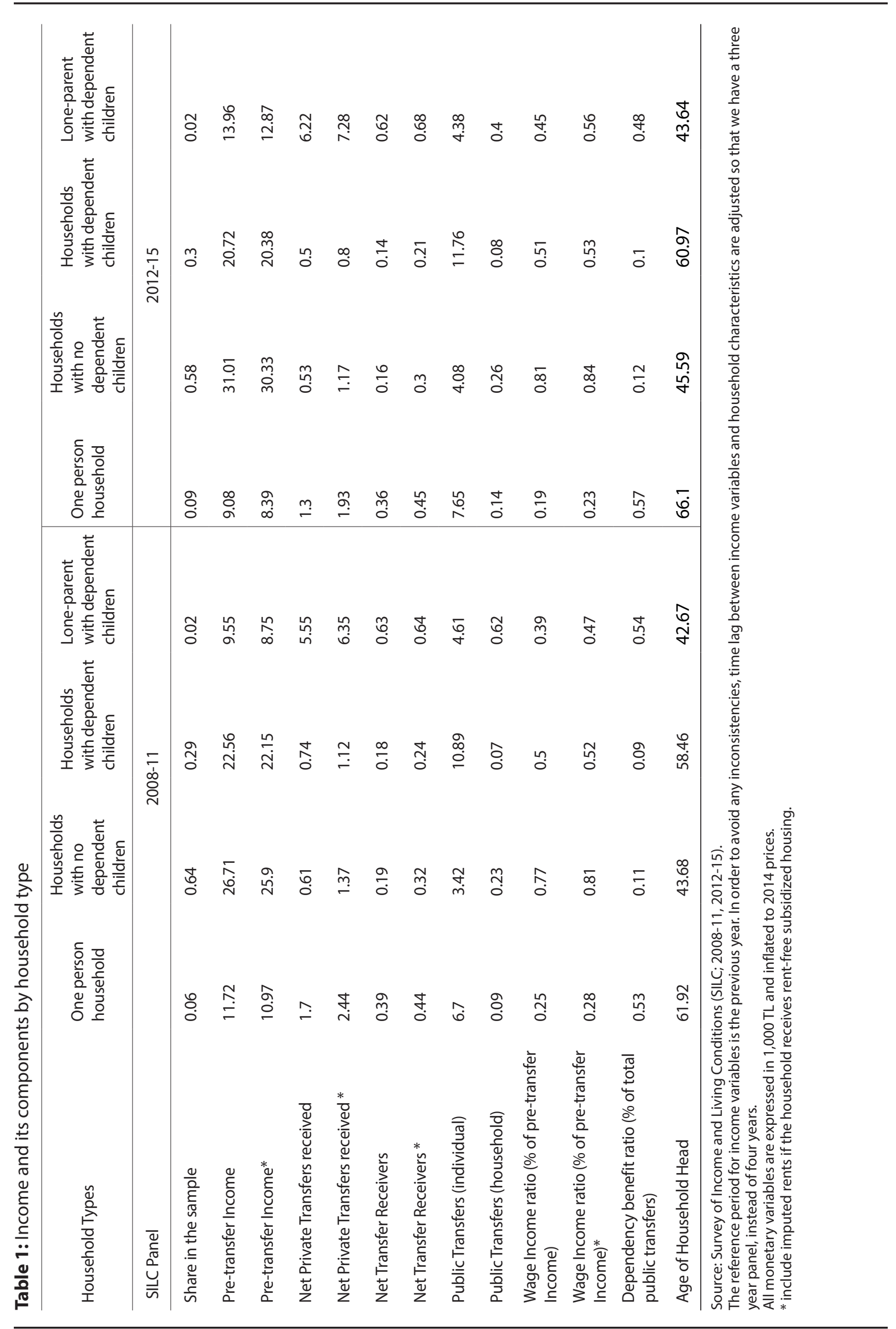




\section{DATA}

To evaluate the interaction between public and private transfers in Turkey, we use Turkstat's Survey on Income and Living Conditions (SILC). ${ }^{3}$ SILC is a unique data source designed with a panel structure to represent Turkey's overall non-institutional population. It provides rich information on household income and indebtedness, household members' labor force status and demographic characteristics like gender, age and educational attainment. ${ }^{4}$ To understand the longitudinal interaction between transfers and household income, we use two consecutive SILC panels, covering 2008 and 2015. We prefer to use a balanced sample for each round to eliminate attritions and households with missing information.

For the sake of comparison, income variables are calculated in real amounts according to the base year 2014. There are several limitations related to the earnings structure for the SILC data. The information on personal and household earnings belongs to the previous year whereas the questionnaire data concerns households' current state. That is, the reference period for questions related to income is one year prior to the interview. Thus, we need to adjust our time-variant household characteristics with the earnings information (lacovou et al., 2012). Matching earnings information with household characteristics means dropping the final year's data and restricting the panel to three years. The first panel, 2008-2010, includes 2,618 households while the second panel, 2012-2014, covers 5,048 households. Note that SILC survey only provides information on total private transfers received at the household level. Thus, all estimations in this paper are carried out at the household level.

We use two different types of dependent variables for the amount of received private transfer. The first is net private transfer, defined as regular inter-household cash or in-kind transfers received minus regular inter-household cash or in-kind transfers paid. ${ }^{5}$ Second, we use an alternative and more comprehensive dependent variable that includes imputed rent for tenants in rent-free or rent-subsidized housing. Because this housing support has a regular character, we consider subsidized rent as a private transfer. Households living rent-free or paying a reduced rent represent around 16 percent of our total sample.

The first predictor, pre-transfer income, is calculated as the total household income net of taxes, and private and public transfers. The second main predictor is public transfers, which are crucial for measuring crowding out. It should be noted that SILC data provides no accurate information on whether household members meet certain conditions for entitlement or eligibility to receive social transfers. To refine the crowding-out effect, we distinguish two types of public transfers: individual-level benefits and household-level benefits. Individual-level benefits cover unemployment insurance benefits (UI), retirement benefits, retirement grants, survivor's benefits, disability benefits and educational benefits received in the reference period. Household-level benefits include in-cash housing allowances, in-cash and in-kind child allowances, and other social allowances received in the reference period. Table 2 summarizes the sample characteristics of the two consecutive panel waves. Approximately one fifth of the sample receives net transfers from other households. While the received positive net transfer amount has not changed significantly, pre-transfer income and public transfers have increased. The increase in the amount of public transfers is slightly larger than pre-transfer income. Another important point is the number of female-headed households increased from 10 to 15 percent over the period under study. The percentage of households where the head or spouse has social security coverage is barely higher in the second panel wave. Note that household heads have become more educated while the marriage rate and household size have decreased. These findings are in line with the transformation of family structure and household composition in Turkey. Lastly, the proportion of households facing financial issues is striking: about a quarter of households report debt issues although the subjective assessment of financial difficulty, i.e. households reporting they are unable to make ends meet, is decreasing. 
Table 2: Summary Statistics

\begin{tabular}{|c|c|c|c|c|}
\hline & \multicolumn{2}{|c|}{ Panel 2008-11 } & \multicolumn{2}{|c|}{ Panel 2012-15 } \\
\hline & Mean & Std. Dev. & Mean & Std. Dev. \\
\hline Net Private Transfers received & 0.80 & 2.84 & 0.72 & 2.98 \\
\hline Net Private Transfers received (incl. subsidized rents) & 1.45 & 3.49 & 1.26 & 3.49 \\
\hline Net Transfer Receivers & 0.21 & 0.40 & 0.19 & 0.39 \\
\hline Net Transfer Receivers (incl. subsidized rents) & 0.31 & 0.46 & 0.30 & 0.46 \\
\hline Pre-transfer Income & 24.37 & 23.95 & 25.52 & 26.98 \\
\hline Pre-transfer Income (incl. subsidized rents) & 23.68 & 23.95 & 24.93 & 26.95 \\
\hline Public Transfers (Individual) & 5.78 & 9.82 & 6.73 & 10.05 \\
\hline Public Transfers (household) & 0.18 & 0.74 & 0.20 & 0.81 \\
\hline \multicolumn{5}{|l|}{ Family Type } \\
\hline One person household & 0.05 & 0.22 & 0.09 & 0.28 \\
\hline Households with no dependent children & 0.64 & 0.48 & 0.59 & 0.49 \\
\hline Households with dependent children* & 0.28 & 0.45 & 0.30 & 0.46 \\
\hline Lone-parent with dependent children & 0.02 & 0.14 & 0.02 & 0.15 \\
\hline Female Household Head & 0.10 & 0.30 & 0.15 & 0.35 \\
\hline Age of Household Head & 48.05 & 14.05 & 51.26 & 14.79 \\
\hline \multicolumn{5}{|l|}{ Head Education Level } \\
\hline Less than primary 5 years* & 0.16 & 0.36 & 0.17 & 0.38 \\
\hline Primary 5 years & 0.47 & 0.50 & 0.45 & 0.50 \\
\hline Primary 8 years & 0.10 & 0.30 & 0.10 & 0.30 \\
\hline Secondary & 0.09 & 0.29 & 0.07 & 0.26 \\
\hline Vocational Sec. & 0.07 & 0.26 & 0.08 & 0.27 \\
\hline Post-Secondary & 0.10 & 0.31 & 0.12 & 0.33 \\
\hline Social Sec. head or spouse & 0.60 & 0.49 & 0.60 & 0.49 \\
\hline \multicolumn{5}{|l|}{ Head Marital Status } \\
\hline Married* & 0.87 & 0.33 & 0.82 & 0.39 \\
\hline Never married & 0.03 & 0.16 & 0.03 & 0.16 \\
\hline Spouse died & 0.08 & 0.27 & 0.13 & 0.33 \\
\hline Divorced & 0.02 & 0.15 & 0.03 & 0.18 \\
\hline Head - health-related limitations past 6 months & 0.31 & 0.46 & 0.32 & 0.47 \\
\hline Household - difficulty in loan payments & 0.25 & 0.43 & 0.24 & 0.43 \\
\hline Owner* & 0.61 & 0.49 & 0.63 & 0.48 \\
\hline Tenant & 0.23 & 0.42 & 0.20 & 0.40 \\
\hline Subsidised housing (rent-free) & 0.16 & 0.37 & 0.16 & 0.37 \\
\hline Household unable to make ends meet & 0.24 & 0.43 & 0.17 & 0.38 \\
\hline Household size & 4.00 & 1.98 & 3.87 & 2.11 \\
\hline Number of Households & \multicolumn{2}{|c|}{2,618} & \multicolumn{2}{|c|}{5,048} \\
\hline
\end{tabular}

Source: Survey of Income and Living Conditions (SILC; 2008-11, 2012-15).

The reference period for income variables is the previous year. In order to avoid any inconsistencies, time lag between income variables and household characteristics are adjusted so that we have a three year panel, instead of four years.

All monetary variables are expressed in 1,000 TL and inflated to 2014 prices.

* indicates omitted categories used in estimations.

\section{IDENTIFICATION STRATEGY}

We use two empirical models to estimate motives for private transfers. Following previous literature, we begin with a binary response model, namely the random effect probit model, to identify factors affecting private transfers on the extensive margin. For the second model, we use a censored regression tobit model to estimate the crowding out/in effects on the 
intensive margin. The basic regression equation could be specified as:

$$
T_{i, t}=\beta_{0}+\beta_{1} I_{i, t}+\beta_{2} P_{i, t}+\gamma X_{i, t}+v_{i}+\varepsilon_{i, t}
$$

where net receiver $T_{i}$ takes the value 1 in the probit model and the observed amount in the tobit model if the household receives a positive transfer (cash or inkind) net of transfers from other households. Otherwise, it takes $0 .{ }^{6} I_{i, t}$ indicates the pre-transfer income and $P_{i, t}$ is the public transfers. As an alternative definition of the outcome variable, we adjust the dependent variable when the household has rent-free housing by adding the imputed rent to the private transfer and subtracting it from the pre-transfer income. In line with the predictions of the literature, we expect that when $\beta_{1}<0$ , private transfers are altruistically motivated whereas $\beta_{1}>0$ suggests that there is an exchange motive (impure altruism) (Cox, 1987). The coefficient $\beta_{2}<0$ implies that public transfers crowd out private transfers.

$X_{i, t}$ is a vector of variables giving information on the household and its head as reported in SILC. Household head characteristics include information about gender, age, education (category) level, marital status (category), health status (physically handicapped in the past 6 months) and social security registration (head or spouse has registered with the social security system ). ${ }^{7}$ The following household characteristics are controlled for: household size, difficulty in paying debt, subjective evaluation of economic hardship (household can not make ends meet without great difficulty) and dwelling type (excluded in the alternative model when imputed rent is added). $v_{i}$ is the unobserved, time-invariant, individual specific effect while $\varepsilon_{i t}$ is the error term assumed to be normally distributed with mean 0 and variance 1 .

$$
P\left(T_{i, t}=1 \mid X_{i}\right)=\Phi\left[\left(\psi+X_{i, t} \beta+\lambda \bar{X}_{i}\right)\left(1+\sigma_{a}^{2}\right)^{-\frac{1}{2}}\right]
$$

For the sake of simplicity, we multiply Eq. 3 by $\left(1+\sigma_{a}^{2}\right)^{-\frac{1}{2}}$ to obtain the following parameter vector to be estimated:

$$
P\left(T_{i, t}=1 \mid X_{i}\right)=\Phi\left[\left(\psi_{a}+X_{i, t} \beta_{a}+\lambda_{a} \bar{X}_{i}\right)\right]
$$

The standard maximum likelihood approach is used to estimate the coefficients of the model. The following likelihood function is maximised using Stata software:
There are several identification issues to address. The first is endogeneity bias, which can arise when individuals who expect a private transfer in the next period, might prefer working less. Therefore, full information on receiving private transfers might decrease pre-transfer income. This incentive mechanism implies that private transfers can condition pre-transfer income through labor supply decisions. Theoretically, it resembles the case of endogenous income in an altruistic setting where the receivers are more likely to exert less effort if they expect a transfer (Laferrère and Wolff, 2006). ${ }^{8}$ To deal with the potential endogeneity of receiving private transfers and pre-transfer income, we apply a dynamic panel approach using the lagged value of pre-transfer income and refine the basic model with a correlated random effects (CRE) approach.

It is hard to assume that the orthogonality assumption $E\left(X_{i t}\left(v_{i}+\varepsilon_{i t}\right)\right)$ holds in the basic set-up. The Chamberlain-Mundlak correlated random effects probit model (Chamberlain, 1984) offers an alternative approach allowing for the potential correlation between observed and unobserved variables. In this approach, the distribution of ${ }^{v_{i}}$ conditional on $X_{i} ; D\left(v_{i} X_{i}\right)$ is specified in a parametric setting (Wooldridge, 2010). Thus, the unobserved individual effect can be written as follows:

$$
v_{i}=\psi+\lambda \bar{X}_{i}+a_{i}, a_{i} \mid X_{i} \sim N\left(0, \sigma_{a}\right)
$$

where $\bar{X}_{i}$ is the vector containing the average values of time-variant independent variables, $\psi$ is a constant and $a_{i}$ is the i.i.d. error term. Put differently, in the CRE model framework, we impose a linear relationship between unobservables and observables, and assume that the conditional variance of the unobserved effect is constant. We use the following specification of a standard CRE probit model:

$$
t=1, \ldots, T
$$

$$
\mathcal{L}=\prod\left(1-\Phi\left(\psi_{a}+X_{i, t} \beta_{a}+\lambda_{a} \bar{X}_{i}\right)\right)\left(\Phi\left(\psi_{a}+X_{i, t} \beta_{a}+\lambda_{a} \bar{X}_{i}\right)\right)
$$


Evaluating the amounts of private transfers makes it necessary to deal with the " 0 observation" problem given that a large number of households are censored at zero. Therefore, following the relevant literature, we use a tobit model in addition to the binary model described above (Reil-Held, 2006; Schoeni, 1997). $T_{i, t}$ takes a positive value if the household is a net receiver and 0 if it is censored while other variables remain unchanged. In this censored case, we have the same model for $D\left(v_{i} \mid X_{i}\right)$ as in Equation 2. The averages of the time-variant characteristics are again used to estimate the unobservable individual specific effect. Finally, we perform an MLE to obtain the coefficients of the CRE tobit model.

The ratio $\rho$ (rho) reported in Tables 4-7 shows the proportion of the total variance contributed by the panel-level variance component. $\rho$ is defined as follows:

$$
\begin{aligned}
& \frac{\sigma_{u}^{2}}{\sigma_{u}^{2}+1} \text { for the probit estimation, and } \\
& \frac{\sigma_{u}^{2}}{\sigma_{u}^{2}+\sigma_{\epsilon}^{2}} \text { for the tobit estimation respectively. }
\end{aligned}
$$

If $\rho$ converges to zero, this means that the panel variance component is unimportant, and the panel estimator is not different from the pooled estimator.

Another potential bias is multicollinearity due to correlations between social transfers and pre-transfer income or if the public transfer scheme is means tested. Such a correlation may make the estimated coefficients inaccurate. However, Turkey's social welfare system does not depend heavily on means-tested benefits. Besides, the distinction between individual and household-level public transfer can differentiate the entitlement to social assistance programs. The expectations and timing of private transfers is also crucial. If it is not regular and substantial, it may satisfy a precautionary need. Even though the panel structure partially overcomes the identification problems due to endogeneity, we observe a strong dependence on private transfers after adding subsidized rent. Thus, it is hard to identify the household through an IV procedure if this relationship is permanent. Table 3 gives information on the dependency of households for receiving positive net transfers within a 4-year panel.

\begin{tabular}{|c|c|c|c|c|c|c|c|c|}
\hline & \multicolumn{4}{|c|}{ Narrow Definition } & \multicolumn{4}{|c|}{ Broad Definition } \\
\hline & \multicolumn{2}{|c|}{ 2008-11 } & \multicolumn{2}{|c|}{$2012-15$} & \multicolumn{2}{|c|}{$2008-11$} & \multicolumn{2}{|c|}{ 2012-15 } \\
\hline & & $\%$ & & $\%$ & & $\%$ & & $\%$ \\
\hline Never received a transfer & 1666 & 63.6 & 3352 & 66.4 & 1443 & 55.1 & 2862 & 56.7 \\
\hline Received at least once & 952 & 36.4 & 1696 & 33.6 & 1175 & 44.9 & 2186 & 43.3 \\
\hline 1 year & 360 & 37.8 & 654 & 38.6 & 308 & 26.2 & 565 & 25.8 \\
\hline 2 year & 235 & 24.7 & 393 & 23.2 & 205 & 17.4 & 377 & 17.2 \\
\hline 3 year & 178 & 18.7 & 323 & 19 & 193 & 16.4 & 352 & 16.1 \\
\hline 4 year & 179 & 18.8 & 326 & 19.2 & 469 & 39.9 & 892 & 40.8 \\
\hline No. Households & 2618 & & 5048 & & 2618 & & 5048 & \\
\hline
\end{tabular}

Table 3: Household receiving private transfers in the panel

Source: SILC Panel 2008-11, 2012-15

The reference period for income variables is the previous year.

\section{RESULTS AND DISCUSSION}

Tables 4 and 5 display the estimated coefficients from the tobit model, which gives a broader perspective via its levels-based estimation procedure. ${ }^{9}$ In Tables 6 and 7, the coefficients from probit regression are presented. Column a in each table shows the results for the random effects models. Column $b$ in each table shows the dynamic regression that included a lagged variable of being a net receiver. We expected a decrease in the key variable after including the lagged value of the dependent variable since it might show how much past transfer history can capture unobserved household characteristics. In other words, a lagged state variable might indicate whether receiving transfers is temporary or permanent. The last two columns of each table report estimated coefficients for the CRE model using two separate panel data sets. Panel variance component $(\rho)$ is not negligible except the dynamic probit regression. As seen from Tables 6 and 7, including the lagged dependent variable into the probit regression, decreases the panel-level variance component towards 
zero, hence it translates the regression into the pooled estimator. By taking into account the short spell of the dataset, it seems plausible for the binary case. However, the panel level variance component remains significant in the tobit estimation when the lagged dependent variable is included (Tables 4 and 5). On the other hand, controlling for unobserved heterogeneity by CRE, increases $\rho$ slightly in all specifications. In the tobit regressions, the second wave of the panel yields greater panel-level variance component estimates whereas they do not differ significantly from each other in the probit case.

The parameters in Table 5 were estimated by considering subsidized rent as a component of private transfers. This provides a more dependent sample in terms of private transfers since subsidized housing is permanent. Although we lack information about donors, we can intuitively expect that parents tend to support their children financially if their income is less than their parents.

These results provide evidence that private transfers in Turkey are motivated by altruism. Whether narrowly or broadly defined, private transfers decrease with pre-transfer income for both sub-periods. Note that the altruism parameter slightly decreases during 20102013, when the amount of transfers and pre-transfer income changes with household types, as seen from Table 1. Compared to the narrowly defined case, including subsidized rent lowers the altruistic motive. In other words, the level of pre-transfer income has a lower impact on receiving private transfers when subsidized rent is included. In the CRE model, which is supposed to control for unobserved heterogeneity, the estimated coefficients decrease as expected.

Our results indicate that female-headed households are more likely to receive private transfers, confirming Cox and Jimenez (1990), Cox et al. (1998), Cox et al. (2004), and Kaufmann and Lindauer (1986). The estimated coefficient decreases over time in both the dynamic model and CRE model with the lagged variable. One explanation for this gender difference could be what we can call expected parent care in the future, which provides an insight into the exchange motive. This finding is also in line with Ezemenari (1997), who reports a non-linear age-dependent relationship between public and private transfers. For females under age thirty-five altruism dominates whereas the exchange motive is more influential for older women.
Our second main finding is the crowding out effect of individual public transfers. Individual public transfers, which have a more permanent character, crowd out private transfers in all specifications. The magnitude of the crowding out effect coefficient decreases over time. Although including imputed rent in the regression reduces the effect, it remains significant. The CRE model and including the lagged value of the dependent variable also yield smaller coefficients. Thus, uncontrolled unobserved heterogeneity apparently leads to overestimating the crowding out effect.

Regarding transfers to households, public transfers had no significant effect on private ones (Tables 4 and 5). This may be because household targeted public transfers are lower than individual ones (Table 2), so receiving small public transfers do not change the altruistic behavior of donors. Another interesting finding is that the age of the household head is significant in the broad model in that younger households receive more private transfers after housing support is included. The dependency on private transfers increases significantly with the broad definition (Table 3), which indicates that downstream transfers from parents to their children is a significant phenomenon in Turkey. Households whose head has received at least 8 years of education receive higher private transfers, which may also be due to the exchange motive. On the other hand, considering that educational mobility is quite low in Turkey (Akarçay-Gürbüz and Polat, 2017), educated individuals may be receiving private transfers because of their wealthier family background.

Households lacking social security coverage are more likely to receive private transfers, as expected. A non-negligible part of population such as agricultural workers/self-employed/unpaid family workers have not been entirely covered by the social security system in Turkey. It seems that inter-household transfers provide an important funding for informal safety nets. Note that agricultural workers are not generally registered with any social security institution in Turkey while upstream transfers from urban to rural areas are common. It seems that this effect is more robust in the second period for the both models. Family type has a particular social attribute. One-person households only receive more transfers during 2008-2011 as this coefficient loses significance in the second wave. In both models, lone parents with children receive more transfers than families with more than two adults and children. Household size has a negative effect because intra-household transfers grow as family size increases. 
However, its coefficient becomes insignificant in the CRE specification and is captured by its average level below, especially for the second wave. The coefficients for indebtedness of households are mostly insginificant in the different specifications, except for the CRE model, in which the time-average levels of this variable yield positive coefficients. Households who report having financial difficulties are more likely to receive private transfers in the basic model without the lagged dependent variable, especially for the first period. This variable also becomes insignificant when average levels are included in the regression.

Table 4: Panel Tobit Model with Random Effects

\begin{tabular}{|c|c|c|c|c|c|c|c|c|}
\hline \multirow[b]{2}{*}{$\begin{array}{l}\text { Dep. var: Net transfer receiver } \\
\text { (excl. subs. rents) }\end{array}$} & \multicolumn{4}{|c|}{ Panel 2008-2011 } & \multicolumn{4}{|c|}{ Panel 2012-2015 } \\
\hline & $\mathrm{RE}$ & $\mathrm{RE}$ & CRE & CRE & $\mathrm{RE}$ & $\mathrm{RE}$ & $\begin{array}{l}\text { CRE } \\
\text { (g) }\end{array}$ & CRE \\
\hline \multirow[t]{2}{*}{$\begin{array}{l}\text { Previous year status (net } \\
\text { receiver }=1 \text { ) }\end{array}$} & & $5.506^{* * *}$ & & $5.469^{* * *}$ & & $6.049 * * *$ & & $5.990^{* * *}$ \\
\hline & & $(0.379)$ & & $(0.378)$ & & $(0.284)$ & & $(0.285)$ \\
\hline \multirow[t]{2}{*}{ Pre-transfer income (1000 tl) } & $-0.137^{* * *}$ & $-0.111^{* * *}$ & $-0.133^{* * *}$ & $-0.108^{* * *}$ & $-0.117^{* * *}$ & $-0.086^{* * *}$ & $-0.111^{* * *}$ & $-0.083^{* * *}$ \\
\hline & $(0.011)$ & $(0.010)$ & $(0.011)$ & $(0.010)$ & $(0.008)$ & $(0.007)$ & $(0.008)$ & $(0.007)$ \\
\hline \multirow[t]{2}{*}{ Public transfers (individual) } & $-0.235^{* * *}$ & $-0.177^{* * *}$ & $-0.232^{* * *}$ & $-0.176^{* * *}$ & $-0.221^{* * *}$ & $-0.154^{* * *}$ & $-0.213^{* * *}$ & $-0.151^{* * *}$ \\
\hline & $(0.026)$ & $(0.023)$ & $(0.026)$ & $(0.023)$ & $(0.019)$ & $(0.016)$ & $(0.019)$ & $(0.017)$ \\
\hline \multirow[t]{2}{*}{ Public transfers (household) } & -0.152 & -0.272 & -0.176 & -0.292 & 0.067 & 0.052 & 0.041 & 0.035 \\
\hline & $(0.164)$ & $(0.160)$ & $(0.165)$ & $(0.161)$ & $(0.096)$ & $(0.098)$ & $(0.097)$ & $(0.098)$ \\
\hline \multirow[t]{2}{*}{ Female household head } & $6.004^{* * *}$ & $5.780 * * *$ & $5.861^{* * *}$ & $5.679^{* * *}$ & $6.144^{* * *}$ & $5.566^{* * *}$ & $6.154^{* * *}$ & $5.575^{* * *}$ \\
\hline & $(0.694)$ & $(0.627)$ & $(0.697)$ & $(0.629)$ & $(0.483)$ & $(0.443)$ & $(0.485)$ & $(0.445)$ \\
\hline \multirow[t]{2}{*}{ Age of household head } & 0.017 & 0.016 & 0.007 & 0.009 & -0.009 & 0.003 & -0.014 & 0.000 \\
\hline & $(0.017)$ & $(0.014)$ & $(0.018)$ & $(0.015)$ & $(0.013)$ & $(0.011)$ & $(0.013)$ & $(0.011)$ \\
\hline \multirow[t]{2}{*}{ Primary 5 years } & 0.126 & 0.594 & 0.288 & 0.683 & -0.311 & 0.095 & -0.164 & 0.143 \\
\hline & $(0.508)$ & $(0.418)$ & $(0.511)$ & $(0.420)$ & $(0.409)$ & $(0.336)$ & $(0.413)$ & $(0.339)$ \\
\hline \multirow[t]{2}{*}{ Primary 8 years } & $1.490^{*}$ & $1.700^{* *}$ & $1.671^{*}$ & $1.801^{* *}$ & 0.694 & $0.989^{*}$ & 0.911 & $1.065^{*}$ \\
\hline & $(0.707)$ & $(0.577)$ & $(0.711)$ & $(0.579)$ & $(0.579)$ & $(0.474)$ & $(0.584)$ & $(0.477)$ \\
\hline \multirow[t]{2}{*}{ Secondary } & $2.353^{* *}$ & $2.386^{* * *}$ & $2.680^{* * *}$ & $2.573^{* * *}$ & $2.135^{* * *}$ & $2.135^{* * * *}$ & $2.395^{* * *}$ & $2.228^{* * *}$ \\
\hline & $(0.756)$ & $(0.616)$ & $(0.764)$ & $(0.621)$ & $(0.629)$ & $(0.517)$ & $(0.635)$ & $(0.520)$ \\
\hline \multirow[t]{2}{*}{ Vocational sec. } & $1.729^{*}$ & $1.766^{* *}$ & $2.010^{*}$ & $1.930^{* *}$ & 1.109 & $1.397^{* *}$ & $1.395^{*}$ & $1.495^{* *}$ \\
\hline & $(0.821)$ & $(0.665)$ & $(0.827)$ & $(0.668)$ & $(0.646)$ & $(0.529)$ & $(0.653)$ & $(0.533)$ \\
\hline \multirow[t]{2}{*}{ Post-secondary } & $2.376^{* *}$ & $2.777^{* * *}$ & $2.797^{* * *}$ & $3.016^{* * *}$ & $1.303^{*}$ & $1.765^{* *}$ & $1.658^{*}$ & $1.896^{* * *}$ \\
\hline & $(0.823)$ & $(0.678)$ & $(0.834)$ & $(0.684)$ & $(0.652)$ & $(0.541)$ & $(0.661)$ & $(0.546)$ \\
\hline \multirow[t]{2}{*}{ Social sec. head or spouse } & $-0.771^{*}$ & -0.439 & $-0.667^{*}$ & -0.362 & $-1.132^{* * *}$ & $-0.663^{* *}$ & $-1.040^{* * *}$ & $-0.627^{* *}$ \\
\hline & $(0.314)$ & $(0.289)$ & $(0.316)$ & $(0.291)$ & $(0.260)$ & $(0.241)$ & $(0.262)$ & $(0.242)$ \\
\hline \multirow[t]{2}{*}{ Never married } & -0.733 & -1.067 & -0.672 & -1.035 & 0.544 & 0.669 & 0.518 & 0.664 \\
\hline & $(0.977)$ & $(0.843)$ & $(0.978)$ & $(0.844)$ & $(0.785)$ & $(0.662)$ & $(0.788)$ & $(0.664)$ \\
\hline \multirow[t]{2}{*}{ Spouse died } & $-5.808^{* * *}$ & $-6.218^{* * *}$ & $-5.848^{* * *}$ & $-6.239^{* * *}$ & $-4.111^{* * *}$ & $-4.622^{* * *}$ & $-4.127^{* * * *}$ & $-4.625^{* * *}$ \\
\hline & $(0.730)$ & $(0.686)$ & $(0.732)$ & $(0.687)$ & $(0.523)$ & $(0.492)$ & $(0.525)$ & $(0.493)$ \\
\hline \multirow[t]{2}{*}{ Divorced } & $-2.141^{*}$ & $-3.542^{* * * *}$ & $-2.296^{*}$ & $-3.635^{* * *}$ & 0.765 & -0.902 & 0.654 & -0.938 \\
\hline & (1.018) & $(0.884)$ & $(1.021)$ & $(0.888)$ & $(0.643)$ & $(0.573)$ & $(0.645)$ & $(0.574)$ \\
\hline $\begin{array}{l}\text { Head - health-related } \\
\text { limitations past } 6 \text { months }\end{array}$ & 0.446 & 0.329 & 0.063 & -0.154 & $0.529^{*}$ & $0.429^{*}$ & 0.266 & 0.237 \\
\hline
\end{tabular}




\begin{tabular}{|c|c|c|c|c|c|c|c|c|}
\hline & $(0.264)$ & $(0.263)$ & $(0.296)$ & $(0.324)$ & $(0.206)$ & $(0.208)$ & $(0.233)$ & $(0.256)$ \\
\hline $\begin{array}{l}\text { Household - difficulty in loan } \\
\text { payments }\end{array}$ & $\begin{array}{l}-0.123 \\
(0.262)\end{array}$ & $\begin{array}{l}-0.276 \\
(0.266)\end{array}$ & $\begin{array}{l}-0.275 \\
(0.288)\end{array}$ & $\begin{array}{l}-0.486 \\
(0.315)\end{array}$ & $\begin{array}{l}-0.275 \\
(0.207)\end{array}$ & $\begin{array}{l}-0.402 \\
(0.214)\end{array}$ & $\begin{array}{l}-0.333 \\
(0.228)\end{array}$ & $\begin{array}{l}-0.508^{*} \\
(0.252)\end{array}$ \\
\hline One person household & $\begin{array}{l}1.421^{*} \\
(0.712)\end{array}$ & $\begin{array}{l}1.541^{*} \\
(0.640)\end{array}$ & $\begin{array}{l}1.505^{*} \\
(0.714)\end{array}$ & $\begin{array}{l}1.605^{*} \\
(0.642)\end{array}$ & $\begin{array}{l}0.065 \\
(0.472)\end{array}$ & $\begin{array}{l}0.327 \\
(0.435)\end{array}$ & $\begin{array}{l}0.127 \\
(0.474)\end{array}$ & $\begin{array}{l}0.360 \\
(0.437)\end{array}$ \\
\hline $\begin{array}{l}\text { Households with no } \\
\text { dependent children }\end{array}$ & $\begin{array}{l}-0.527 \\
(0.439)\end{array}$ & $\begin{array}{l}-0.595 \\
(0.394)\end{array}$ & $\begin{array}{l}-0.582 \\
(0.440)\end{array}$ & $\begin{array}{l}-0.634 \\
(0.395)\end{array}$ & $\begin{array}{l}1.039^{* *} \\
(0.344)\end{array}$ & $\begin{array}{l}0.906^{* *} \\
(0.317)\end{array}$ & $\begin{array}{l}1.037^{* *} \\
(0.346)\end{array}$ & $\begin{array}{l}0.901^{* *} \\
(0.318)\end{array}$ \\
\hline $\begin{array}{l}\text { Lone-parent with dependent } \\
\text { children }\end{array}$ & $\begin{array}{l}3.575^{* * *} \\
(0.938)\end{array}$ & $\begin{array}{l}3.857^{* * * *} \\
(0.869)\end{array}$ & $\begin{array}{l}3.572^{* * *} \\
(0.938)\end{array}$ & $\begin{array}{l}3.833^{* * *} \\
(0.870)\end{array}$ & $\begin{array}{l}3.949 * * * \\
(0.673)\end{array}$ & $\begin{array}{l}5.012^{* * *} \\
(0.622)\end{array}$ & $\begin{array}{l}3.944^{* * *} \\
(0.675)\end{array}$ & $\begin{array}{l}4.996 * * * \\
(0.624)\end{array}$ \\
\hline $\begin{array}{l}\text { Household unable to make } \\
\text { ends meet }\end{array}$ & $\begin{array}{l}0.535^{*} \\
(0.249)\end{array}$ & $\begin{array}{l}0.228 \\
(0.258)\end{array}$ & $\begin{array}{l}0.370 \\
(0.269)\end{array}$ & $\begin{array}{l}0.070 \\
(0.298)\end{array}$ & $\begin{array}{l}0.249 \\
(0.208)\end{array}$ & $\begin{array}{l}0.197 \\
(0.220)\end{array}$ & $\begin{array}{l}-0.081 \\
(0.222)\end{array}$ & $\begin{array}{l}-0.052 \\
(0.249)\end{array}$ \\
\hline Household size & $\begin{array}{l}-0.128 \\
(0.096)\end{array}$ & $\begin{array}{l}-0.007 \\
(0.083)\end{array}$ & $\begin{array}{l}-0.142 \\
(0.097)\end{array}$ & $\begin{array}{l}-0.019 \\
(0.084)\end{array}$ & $\begin{array}{l}-0.458^{* * *} \\
(0.080)\end{array}$ & $\begin{array}{l}-0.316^{* * *} \\
(0.070)\end{array}$ & $\begin{array}{l}-0.482^{* * *} \\
(0.081)\end{array}$ & $\begin{array}{l}-0.330^{* * *} \\
(0.071)\end{array}$ \\
\hline Tenant & $\begin{array}{l}-0.486 \\
(0.428)\end{array}$ & $\begin{array}{l}-0.275 \\
(0.356)\end{array}$ & $\begin{array}{l}-0.630 \\
(0.432)\end{array}$ & $\begin{array}{l}-0.376 \\
(0.360)\end{array}$ & $\begin{array}{l}-0.552 \\
(0.339)\end{array}$ & $\begin{array}{l}-0.478 \\
(0.289)\end{array}$ & $\begin{array}{l}-0.671 \\
(0.343)\end{array}$ & $\begin{array}{l}-0.540 \\
(0.291)\end{array}$ \\
\hline $\begin{array}{l}\text { Subsidized housing (rent- } \\
\text { free) }\end{array}$ & $\begin{array}{l}2.710^{* * *} \\
(0.430)\end{array}$ & $\begin{array}{l}1.855^{* * *} \\
(0.356)\end{array}$ & $\begin{array}{l}2.646^{* * *} \\
(0.431)\end{array}$ & $\begin{array}{l}1.818^{* * *} \\
(0.357)\end{array}$ & $\begin{array}{l}1.643^{* * *} \\
(0.335)\end{array}$ & $\begin{array}{l}1.111^{* * *} \\
(0.279)\end{array}$ & $\begin{array}{l}1.561^{* * *} \\
(0.337)\end{array}$ & $\begin{array}{l}1.075^{* * *} \\
(0.280)\end{array}$ \\
\hline $\begin{array}{l}\text { Averages of time variant vars. } \\
\text { Head - health-related }\end{array}$ & & & & & & & & \\
\hline limitations past 6 months & & & $\begin{array}{l}1.709^{* *} \\
(0.649)\end{array}$ & $\begin{array}{l}1.364^{*} \\
(0.560)\end{array}$ & & & $\begin{array}{l}1.029^{*} \\
(0.512)\end{array}$ & $\begin{array}{l}0.492 \\
(0.446)\end{array}$ \\
\hline $\begin{array}{l}\text { Household - difficulty in loan } \\
\text { payments }\end{array}$ & & & $\begin{array}{l}0.666 \\
(0.681)\end{array}$ & $\begin{array}{l}0.622 \\
(0.577)\end{array}$ & & & $\begin{array}{l}0.029 \\
(0.568)\end{array}$ & $\begin{array}{l}0.267 \\
(0.486)\end{array}$ \\
\hline $\begin{array}{l}\text { Household unable to make } \\
\text { ends meet }\end{array}$ & & & $\begin{array}{l}0.957 \\
(0.726)\end{array}$ & $\begin{array}{l}0.517 \\
(0.611)\end{array}$ & & & $\begin{array}{l}2.654^{* * *} \\
(0.675)\end{array}$ & $\begin{array}{l}1.121^{*} \\
(0.569)\end{array}$ \\
\hline Constant & $\begin{array}{l}-4.169^{* * *} \\
(1.244)\end{array}$ & $\begin{array}{l}-6.258^{* * *} \\
(1.056)\end{array}$ & $\begin{array}{l}-4.663^{* * *} \\
(1.283)\end{array}$ & $\begin{array}{l}-6.498^{* * *} \\
(1.078)\end{array}$ & $\begin{array}{l}-3.300^{* *} \\
(1.018)\end{array}$ & $\begin{array}{l}-6.436^{* * *} \\
(0.879)\end{array}$ & $\begin{array}{l}-3.939^{* * *} \\
(1.039)\end{array}$ & $\begin{array}{l}-6.686^{* * *} \\
(0.890)\end{array}$ \\
\hline sigma u & $\begin{array}{l}6.127^{* * *} \\
(0.202)\end{array}$ & $\begin{array}{l}3.782^{* * *} \\
(0.224)\end{array}$ & $\begin{array}{l}6.138^{* * *} \\
(0.203)\end{array}$ & $\begin{array}{l}3.805^{* * *} \\
(0.223)\end{array}$ & $\begin{array}{l}6.645^{* * *} \\
(0.160)\end{array}$ & $\begin{array}{l}4.263^{* * *} \\
(0.159)\end{array}$ & $\begin{array}{l}6.672^{* * *} \\
(0.161)\end{array}$ & $\begin{array}{l}4.294^{* * *} \\
(0.160)\end{array}$ \\
\hline sigma e & $\begin{array}{l}4.625^{* * *} \\
(0.100)\end{array}$ & $\begin{array}{l}5.431^{* * *} \\
(0.142)\end{array}$ & $\begin{array}{l}4.621^{* * *} \\
(0.100)\end{array}$ & $\begin{array}{l}5.418^{* * *} \\
(0.142)\end{array}$ & $\begin{array}{l}4.679^{* * *} \\
(0.078)\end{array}$ & $\begin{array}{l}5.520^{* * *} \\
(0.109)\end{array}$ & $\begin{array}{l}4.681^{* * *} \\
(0.078)\end{array}$ & $\begin{array}{l}5.512^{* * *} \\
(0.109)\end{array}$ \\
\hline rho & $\begin{array}{l}0.637 \\
(0.017)\end{array}$ & $\begin{array}{l}0.327 \\
(0.032)\end{array}$ & $\begin{array}{l}0.638 \\
(0.017)\end{array}$ & $\begin{array}{l}0.330 \\
(0.032)\end{array}$ & $\begin{array}{l}0.669 \\
(0.012)\end{array}$ & $\begin{array}{l}0.374 \\
(0.022)\end{array}$ & $\begin{array}{l}0.670 \\
(0.012)\end{array}$ & $\begin{array}{l}0.378 \\
(0.023)\end{array}$ \\
\hline Observations & 7,854 & 7,854 & 7,854 & 7,854 & 15,144 & 15,144 & 15,144 & 15,144 \\
\hline Number Households & 2,618 & 2,618 & 2,618 & 2,618 & 5,048 & 5,048 & 5,048 & 5,048 \\
\hline
\end{tabular}

Robust standard errors in parentheses, ${ }^{* * *} p<0.001,{ }^{* *} p<0.01,{ }^{*} p<0.05$.

Source: Survey of Income and Living Conditions (2008-11, 2012-15).

The reference period for income variables is the previous year. In order to avoid any inconsistencies, time lag between income variables and household characteristics are adjusted so that we have a three year panel, instead of four years.

Omitted categories for household head are; less than 5 year primary for education level, being married for marital status. Households with dependent children and house ownership are omitted categories for household characteristics.

All monetary variables are expressed in 1,000 TL and inflated to 2014 prices. 
Table 5: Panel Tobit Model with Random Effects - Sample with subsidized rents imputed

\begin{tabular}{|c|c|c|c|c|c|c|c|c|}
\hline \multirow[b]{3}{*}{$\begin{array}{l}\text { Dep. var: Net transfer receiver } \\
\text { (incl. subs. rents) }\end{array}$} & \multicolumn{4}{|c|}{ Panel 2008-2011 } & \multicolumn{4}{|c|}{ Panel 2012-2015 } \\
\hline & RE & $\mathrm{RE}$ & CRE & CRE & RE & RE & CRE & CRE \\
\hline & (a) & (b) & (c) & (d) & (e) & (f) & (g) & (h) \\
\hline \multirow[t]{2}{*}{$\begin{array}{l}\text { Previous year status (net } \\
\text { receiver=1) }\end{array}$} & & $7.385^{* * *}$ & & $7.373^{* * *}$ & & $6.936^{* * *}$ & & $6.918^{* * *}$ \\
\hline & & $(0.312)$ & & $(0.312)$ & & $(0.217)$ & & $(0.219)$ \\
\hline \multirow[t]{2}{*}{ Pre-transfer income (1000 tl) } & $-0.103^{* * *}$ & $-0.076^{* * *}$ & $-0.099 * * *$ & $-0.075^{* * *}$ & $-0.093^{* * *}$ & $-0.061^{* * *}$ & $-0.089 * * *$ & $-0.060^{* * *}$ \\
\hline & $(0.008)$ & $(0.007)$ & $(0.008)$ & $(0.007)$ & $(0.005)$ & $(0.005)$ & $(0.006)$ & $(0.005)$ \\
\hline \multirow[t]{2}{*}{ Public transfers (individual) } & $-0.164^{* * *}$ & $-0.116^{* * *}$ & $-0.160^{* * *}$ & $-0.115^{* * *}$ & $-0.178^{* * * *}$ & $-0.111^{* * *}$ & $-0.172^{* * *}$ & $-0.110^{* * *}$ \\
\hline & $(0.020)$ & $(0.017)$ & $(0.020)$ & $(0.017)$ & $(0.014)$ & $(0.012)$ & $(0.014)$ & $(0.012)$ \\
\hline \multirow[t]{2}{*}{ Public transfers (household) } & -0.160 & -0.246 & -0.178 & -0.256 & 0.026 & -0.024 & 0.008 & -0.029 \\
\hline & $(0.136)$ & $(0.134)$ & $(0.137)$ & $(0.134)$ & $(0.074)$ & $(0.077)$ & $(0.075)$ & $(0.078)$ \\
\hline \multirow[t]{2}{*}{ Female household head } & $4.732^{* * *}$ & $4.775^{* * *}$ & $4.681^{* * *}$ & $4.744^{* * *}$ & $5.040^{* * *}$ & $4.238^{* * *}$ & $5.053^{* * *}$ & $4.244^{* * *}$ \\
\hline & $(0.635)$ & $(0.544)$ & $(0.639)$ & $(0.546)$ & $(0.398)$ & $(0.355)$ & $(0.399)$ & $(0.356)$ \\
\hline \multirow[t]{2}{*}{ Age of household head } & $-0.063^{* * *}$ & $-0.027^{*}$ & $-0.067^{* * *}$ & $-0.030^{*}$ & $-0.055^{* * *}$ & $-0.018^{*}$ & $-0.055^{* * *}$ & -0.017 \\
\hline & $(0.015)$ & $(0.011)$ & $(0.016)$ & $(0.012)$ & $(0.011)$ & $(0.009)$ & $(0.011)$ & $(0.009)$ \\
\hline \multirow[t]{2}{*}{ Primary 5 years } & -0.251 & 0.496 & -0.085 & 0.549 & -0.580 & 0.045 & -0.467 & 0.048 \\
\hline & $(0.492)$ & $(0.360)$ & $(0.497)$ & $(0.362)$ & $(0.361)$ & $(0.271)$ & $(0.364)$ & $(0.273)$ \\
\hline \multirow[t]{2}{*}{ Primary 8 years } & 0.395 & $1.215^{*}$ & 0.571 & $1.267^{* *}$ & 0.311 & $0.873^{*}$ & 0.471 & $0.880^{*}$ \\
\hline & $(0.675)$ & $(0.487)$ & $(0.679)$ & $(0.489)$ & $(0.503)$ & $(0.374)$ & $(0.507)$ & $(0.376)$ \\
\hline \multirow[t]{2}{*}{ Secondary } & 1.238 & $1.711^{* * *}$ & $1.514^{*}$ & $1.794^{* * *}$ & $1.324^{*}$ & $1.718^{* * *}$ & $1.537^{* *}$ & $1.735^{* * *}$ \\
\hline & $(0.713)$ & $(0.516)$ & $(0.721)$ & $(0.520)$ & $(0.552)$ & $(0.412)$ & $(0.557)$ & $(0.414)$ \\
\hline \multirow[t]{2}{*}{ Vocational sec. } & $1.687^{*}$ & $1.842^{* * *}$ & $1.923^{*}$ & $1.914^{* * *}$ & 0.485 & $1.123^{* *}$ & 0.756 & $1.151^{* *}$ \\
\hline & $(0.776)$ & $(0.548)$ & $(0.783)$ & $(0.551)$ & $(0.564)$ & $(0.418)$ & $(0.570)$ & $(0.421)$ \\
\hline \multirow[t]{2}{*}{ Post-secondary } & 0.747 & $2.240^{* * *}$ & 1.108 & $2.342^{* * *}$ & 0.124 & $1.413^{* * *}$ & 0.508 & $1.471^{* * *}$ \\
\hline & $(0.760)$ & $(0.557)$ & $(0.773)$ & $(0.562)$ & $(0.554)$ & $(0.421)$ & $(0.563)$ & $(0.425)$ \\
\hline \multirow[t]{2}{*}{ Social sec. head or spouse } & -0.475 & -0.180 & -0.411 & -0.148 & $-0.466^{*}$ & -0.201 & $-0.401^{*}$ & -0.191 \\
\hline & $(0.264)$ & $(0.237)$ & $(0.265)$ & $(0.238)$ & $(0.201)$ & $(0.184)$ & $(0.202)$ & $(0.185)$ \\
\hline \multirow[t]{2}{*}{ Never married } & -1.596 & $-2.039^{* *}$ & -1.560 & $-2.029 * *$ & 0.138 & 0.780 & 0.111 & 0.771 \\
\hline & $(0.893)$ & $(0.713)$ & $(0.894)$ & $(0.714)$ & $(0.661)$ & $(0.528)$ & $(0.662)$ & $(0.528)$ \\
\hline \multirow[t]{2}{*}{ Spouse died } & $-5.135^{* * *}$ & $-5.707^{* * *}$ & $-5.171 * * *$ & $-5.718^{* * *}$ & $-2.973^{* * *}$ & $-3.574^{* * *}$ & $-2.973^{* * *}$ & $-3.576^{* * *}$ \\
\hline & $(0.649)$ & $(0.593)$ & $(0.650)$ & $(0.593)$ & $(0.420)$ & $(0.389)$ & $(0.421)$ & $(0.389)$ \\
\hline \multirow[t]{2}{*}{ Divorced } & $-2.230^{*}$ & $-3.732^{* * *}$ & $-2.421^{*}$ & $-3.807^{* * *}$ & $1.303^{*}$ & -0.566 & $1.180^{*}$ & -0.591 \\
\hline & $(0.955)$ & $(0.770)$ & $(0.959)$ & $(0.774)$ & $(0.549)$ & $(0.462)$ & $(0.551)$ & $(0.463)$ \\
\hline \multirow{3}{*}{$\begin{array}{l}\text { Head - health-related } \\
\text { limitations past } 6 \text { months }\end{array}$} & & & & & & & & \\
\hline & 0.215 & 0.097 & 0.095 & -0.048 & $0.327^{*}$ & 0.253 & 0.215 & 0.220 \\
\hline & $(0.214)$ & $(0.218)$ & $(0.231)$ & $(0.266)$ & $(0.152)$ & $(0.157)$ & $(0.164)$ & $(0.188)$ \\
\hline \multirow[t]{2}{*}{$\begin{array}{l}\text { Household - difficulty in loan } \\
\text { payments }\end{array}$} & -0.284 & $-0.463^{*}$ & -0.312 & -0.475 & -0.160 & -0.239 & -0.281 & $-0.376^{*}$ \\
\hline & $(0.206)$ & $(0.216)$ & $(0.219)$ & $(0.253)$ & $(0.148)$ & $(0.157)$ & $(0.157)$ & $(0.181)$ \\
\hline \multirow[t]{2}{*}{ One person household } & $2.180^{* * *}$ & $2.035^{* * *}$ & $2.229^{* * * *}$ & $2.058^{* * *}$ & 0.347 & 0.666 & 0.418 & $0.695^{*}$ \\
\hline & $(0.644)$ & $(0.552)$ & $(0.646)$ & $(0.553)$ & $(0.382)$ & $(0.345)$ & $(0.383)$ & $(0.346)$ \\
\hline
\end{tabular}


Households with no

dependent children

$\begin{array}{cccccccc}0.087 & -0.184 & 0.050 & -0.203 & 1.269^{* * *} & 1.011^{* * *} & 1.242^{* * *} & 0.997^{* * *} \\ (0.375) & (0.324) & (0.375) & (0.325) & (0.263) & (0.241) & (0.264) & (0.242) \\ & & & & & & & \\ 3.631^{* * *} & 3.631^{* * *} & 3.612^{* * *} & 3.611^{* * *} & 2.851^{* * *} & 4.349^{* * *} & 2.839^{* * *} & 4.344^{* * *} \\ (0.835) & (0.760) & (0.836) & (0.760) & (0.544) & (0.506) & (0.545) & (0.506)\end{array}$

Lone-parent with dependent children

Household unable to make ends meet

$\begin{array}{cccccccc}0.485^{*} & 0.132 & 0.333 & -0.001 & 0.133 & 0.072 & -0.034 & 0.023 \\ (0.198) & (0.211) & (0.208) & (0.243) & (0.151) & (0.165) & (0.158) & (0.184) \\ -0.263^{* *} & -0.119 & -0.266^{* *} & -0.119 & -0.412^{* * *} & -0.266^{* * *} & -0.441^{* * *} & -0.276^{* * *} \\ (0.087) & (0.070) & (0.088) & (0.071) & (0.065) & (0.054) & (0.066) & (0.055)\end{array}$

Averages of time variant vars.

Head - health-related

limitations past 6 months

$\begin{array}{cccc}0.743 & 0.423 & 0.603 & 0.083 \\ (0.616) & (0.470) & (0.439) & (0.347)\end{array}$

Household - difficulty in loan payments

$\begin{array}{ll}-0.019 & -0.035 \\ (0.645) & (0.475)\end{array}$

$0.874 \quad 0.540$

$\begin{array}{llll}(0.645) & (0.475) & (0.488)\end{array}$

Household unable to make ends meet

$1.526^{*} \quad 0.538 \quad 2.021^{* * *} \quad 0.200$

\begin{tabular}{lccccccccc} 
& & & $(0.695)$ & $(0.508)$ & & & $(0.600)$ & $(0.450)$ \\
Constant & $2.232^{*}$ & $-3.005^{* * *}$ & 1.628 & $-3.146^{* * *}$ & 1.497 & $-4.080^{* * *}$ & 0.643 & $-4.262^{* * * *}$ \\
\multirow{2}{*}{ sigma u } & $(1.094)$ & $(0.862)$ & $(1.143)$ & $(0.884)$ & $(0.832)$ & $(0.681)$ & $(0.856)$ & $(0.690)$ \\
& $6.836^{* * *}$ & $3.436^{* * *}$ & $6.853^{* * *}$ & $3.444^{* * *}$ & $6.821^{* * *}$ & $3.881^{* * *}$ & $6.841^{* * *}$ & $3.889^{* * *}$ \\
sigma e & $(0.184)$ & $(0.171)$ & $(0.184)$ & $(0.172)$ & $(0.132)$ & $(0.113)$ & $(0.133)$ & $(0.114)$ \\
& $3.939^{* * *}$ & $4.875^{* * *}$ & $3.938^{* * *}$ & $4.872^{* * *}$ & $3.749^{* * *}$ & $4.546^{* * *}$ & $3.749^{* * *}$ & $4.545^{* * *}$ \\
rho & $(0.068)$ & $(0.106)$ & $(0.068)$ & $(0.106)$ & $(0.048)$ & $(0.072)$ & $(0.048)$ & $(0.072)$ \\
& 0.751 & 0.332 & 0.752 & 0.333 & 0.768 & 0.421 & 0.769 & 0.423 \\
\hline Observations & $(0.011)$ & $(0.028)$ & $(0.011)$ & $(0.028)$ & $(0.008)$ & $(0.019)$ & $(0.008)$ & $(0.019)$ \\
\hline Number Households & 7,854 & 7,854 & 7,854 & 7,854 & 15,144 & 15,144 & 15,144 & 15,144 \\
\hline
\end{tabular}

Robust standard errors in parentheses, ${ }^{* * *} p<0.001,{ }^{* *} p<0.01,{ }^{*} p<0.05$.

Source: Survey of Income and Living Conditions (2008-11, 2012-15).

The reference period for income variables is the previous year. In order to avoid any inconsistencies, time lag between income variables and household characteristics are adjusted so that we have a three year panel, instead of four years.

Omitted categories for household head are; less than 5 year primary for education level, being married for marital status. Households with dependent children is the omitted category.

All monetary variables are expressed in 1000 TL and inflated to 2014 prices.

Broad definition of private transfers include imputed rents if the household receives rent-free subsidized housing support. 
Table 6: Panel Probit Model with Random Effects - (Marginal Effects)

\begin{tabular}{|c|c|c|c|c|c|c|c|c|}
\hline \multirow[b]{3}{*}{$\begin{array}{l}\text { Dep. var: Net transfer receiver } \\
\text { (excl. subs. rents) }\end{array}$} & \multicolumn{4}{|c|}{ Panel 2008-2011 } & \multicolumn{4}{|c|}{ Panel 2012-2015 } \\
\hline & RE & RE & CRE & CRE & RE & $\mathrm{RE}$ & CRE & CRE \\
\hline & (a) & (b) & (c) & (d) & (e) & (f) & (g) & (h) \\
\hline \multirow[t]{2}{*}{$\begin{array}{l}\text { Previous year status (net } \\
\text { receiver }=1 \text { ) }\end{array}$} & & $0.304^{* * *}$ & & $0.303^{* * *}$ & & $0.281^{* * *}$ & & $0.279^{* * *}$ \\
\hline & & $(0.006)$ & & $(0.006)$ & & $(0.004)$ & & $(0.004)$ \\
\hline \multirow[t]{2}{*}{ Pre-transfer income (1000 tl) } & $-0.004^{* * *}$ & $-0.003^{* * *}$ & $-0.004^{* * *}$ & $-0.003^{* * *}$ & $-0.003^{* * *}$ & $-0.002^{* * *}$ & $-0.003^{* * *}$ & $-0.002^{* * *}$ \\
\hline & $(0.000)$ & $(0.000)$ & $(0.000)$ & $(0.000)$ & $(0.000)$ & $(0.000)$ & $(0.000)$ & $(0.000)$ \\
\hline \multirow[t]{2}{*}{ Public transfers (individual) } & $-0.007^{* * *}$ & $-0.005^{* * *}$ & $-0.007^{* * * *}$ & $-0.005^{* * *}$ & $-0.006^{* * *}$ & $-0.004^{* * *}$ & $-0.006^{* * *}$ & $-0.004^{* * *}$ \\
\hline & $(0.001)$ & $(0.001)$ & $(0.001)$ & $(0.001)$ & $(0.001)$ & $(0.000)$ & $(0.001)$ & $(0.000)$ \\
\hline \multirow[t]{2}{*}{ Public transfers (household) } & -0.002 & -0.006 & -0.003 & -0.007 & 0.004 & $0.006^{*}$ & 0.003 & 0.005 \\
\hline & $(0.005)$ & $(0.005)$ & $(0.005)$ & $(0.005)$ & $(0.003)$ & $(0.003)$ & $(0.003)$ & $(0.003)$ \\
\hline \multirow[t]{2}{*}{ Female household head } & $0.143^{* * *}$ & $0.113^{* * *}$ & $0.138^{* * *}$ & $0.111^{* * *}$ & $0.117^{* * *}$ & $0.088^{* * *}$ & $0.117^{* * *}$ & $0.088^{* * *}$ \\
\hline & $(0.025)$ & $(0.019)$ & $(0.025)$ & $(0.019)$ & $(0.014)$ & $(0.012)$ & $(0.014)$ & $(0.012)$ \\
\hline \multirow[t]{2}{*}{ Age of household head } & 0.001 & $0.001^{*}$ & 0.001 & 0.001 & -0.000 & 0.000 & -0.001 & -0.000 \\
\hline & $(0.001)$ & $(0.000)$ & $(0.001)$ & $(0.000)$ & $(0.000)$ & $(0.000)$ & $(0.000)$ & $(0.000)$ \\
\hline \multirow[t]{2}{*}{ Primary 5 years } & -0.024 & 0.001 & -0.016 & 0.004 & $-0.026^{*}$ & -0.008 & -0.020 & -0.006 \\
\hline & $(0.017)$ & $(0.011)$ & $(0.016)$ & $(0.011)$ & $(0.011)$ & $(0.008)$ & $(0.011)$ & $(0.008)$ \\
\hline \multirow[t]{2}{*}{ Primary 8 years } & 0.026 & 0.028 & 0.034 & $0.032^{*}$ & -0.007 & 0.006 & 0.002 & 0.009 \\
\hline & $(0.026)$ & $(0.016)$ & $(0.026)$ & $(0.016)$ & $(0.016)$ & $(0.011)$ & $(0.016)$ & $(0.011)$ \\
\hline \multirow[t]{2}{*}{ Secondary } & 0.032 & $0.038^{*}$ & 0.047 & $0.044^{*}$ & 0.019 & 0.019 & 0.030 & 0.022 \\
\hline & $(0.029)$ & $(0.018)$ & $(0.030)$ & $(0.018)$ & $(0.020)$ & $(0.013)$ & $(0.020)$ & $(0.013)$ \\
\hline \multirow[t]{2}{*}{ Vocational sec. } & 0.029 & 0.025 & 0.041 & 0.030 & -0.001 & 0.016 & 0.011 & 0.019 \\
\hline & $(0.031)$ & $(0.019)$ & $(0.031)$ & $(0.019)$ & $(0.019)$ & $(0.013)$ & $(0.019)$ & $(0.013)$ \\
\hline \multirow[t]{2}{*}{ Post-secondary } & 0.026 & 0.038 & 0.046 & $0.046^{*}$ & -0.009 & 0.013 & 0.005 & 0.017 \\
\hline & $(0.031)$ & $(0.020)$ & $(0.032)$ & $(0.020)$ & $(0.018)$ & $(0.013)$ & $(0.019)$ & $(0.013)$ \\
\hline \multirow[t]{2}{*}{ Social sec. head or spouse } & $-0.033^{* *}$ & -0.012 & $-0.028^{* *}$ & -0.009 & $-0.035^{* * *}$ & $-0.015^{*}$ & $-0.031^{* * *}$ & $-0.014^{*}$ \\
\hline & $(0.010)$ & $(0.008)$ & $(0.010)$ & $(0.008)$ & $(0.007)$ & $(0.006)$ & $(0.007)$ & $(0.006)$ \\
\hline \multirow[t]{2}{*}{ Never married } & -0.011 & -0.020 & -0.008 & -0.020 & 0.002 & -0.008 & 0.000 & -0.007 \\
\hline & $(0.032)$ & $(0.024)$ & $(0.033)$ & $(0.024)$ & $(0.023)$ & $(0.017)$ & $(0.023)$ & $(0.017)$ \\
\hline \multirow[t]{2}{*}{ Spouse died } & $-0.089^{* * * *}$ & $-0.110^{* * *}$ & $-0.091^{* * *}$ & $-0.110^{* * *}$ & $-0.065^{* * *}$ & $-0.076^{* * *}$ & $-0.066^{* * *}$ & $-0.075^{* * *}$ \\
\hline & $(0.011)$ & $(0.014)$ & $(0.012)$ & $(0.014)$ & $(0.009)$ & $(0.010)$ & $(0.010)$ & $(0.010)$ \\
\hline \multirow[t]{2}{*}{ Divorced } & 0.017 & -0.032 & 0.007 & -0.037 & 0.014 & $-0.030^{*}$ & 0.008 & $-0.032^{*}$ \\
\hline & $(0.042)$ & $(0.025)$ & $(0.040)$ & $(0.025)$ & $(0.022)$ & $(0.014)$ & $(0.021)$ & $(0.014)$ \\
\hline \multirow[t]{2}{*}{$\begin{array}{l}\text { Head-health-related } \\
\text { limitations past } 6 \text { months }\end{array}$} & 0.012 & 0.006 & -0.002 & -0.012 & $0.018^{* *}$ & $0.016^{* *}$ & 0.005 & 0.002 \\
\hline & $(0.009)$ & $(0.008)$ & $(0.010)$ & $(0.011)$ & $(0.006)$ & $(0.006)$ & $(0.006)$ & $(0.008)$ \\
\hline \multirow[t]{2}{*}{$\begin{array}{l}\text { Household - difficulty in loan } \\
\text { payments }\end{array}$} & -0.005 & -0.008 & -0.011 & -0.016 & -0.007 & $-0.015^{*}$ & -0.008 & $-0.016^{*}$ \\
\hline & $(0.009)$ & $(0.009)$ & $(0.010)$ & $(0.011)$ & $(0.006)$ & $(0.006)$ & $(0.006)$ & $(0.008)$ \\
\hline \multirow[t]{2}{*}{ One person household } & 0.045 & $0.046^{*}$ & 0.051 & $0.049^{*}$ & 0.020 & $0.027^{*}$ & 0.023 & $0.029^{*}$ \\
\hline & $(0.032)$ & $(0.023)$ & $(0.033)$ & $(0.023)$ & $(0.013)$ & $(0.011)$ & $(0.013)$ & $(0.012)$ \\
\hline
\end{tabular}




\begin{tabular}{|c|c|c|c|c|c|c|c|c|}
\hline \multirow[t]{2}{*}{$\begin{array}{l}\text { Households with no } \\
\text { dependent children }\end{array}$} & -0.008 & -0.007 & -0.010 & -0.009 & $0.031^{* * *}$ & $0.024^{* *}$ & $0.031^{* * *}$ & $0.024^{* *}$ \\
\hline & $(0.014)$ & $(0.011)$ & $(0.015)$ & $(0.011)$ & $(0.009)$ & $(0.008)$ & $(0.009)$ & $(0.008)$ \\
\hline \multirow[t]{2}{*}{$\begin{array}{l}\text { Lone-parent with dependent } \\
\text { children }\end{array}$} & $0.168^{*}$ & $0.131^{* *}$ & $0.166^{*}$ & $0.126^{* *}$ & $0.152^{* * *}$ & $0.124 * * *$ & $0.147^{* * *}$ & $0.122^{* * *}$ \\
\hline & $(0.068)$ & $(0.041)$ & $(0.066)$ & $(0.041)$ & $(0.037)$ & $(0.024)$ & $(0.036)$ & $(0.024)$ \\
\hline \multirow[t]{2}{*}{$\begin{array}{l}\text { Household unable to make } \\
\text { ends meet }\end{array}$} & $0.024^{* *}$ & 0.011 & 0.013 & -0.007 & 0.010 & 0.011 & -0.007 & -0.011 \\
\hline & $(0.009)$ & $(0.009)$ & $(0.009)$ & $(0.011)$ & $(0.006)$ & $(0.006)$ & $(0.006)$ & $(0.008)$ \\
\hline \multirow[t]{2}{*}{ Household size } & -0.005 & -0.001 & -0.005 & -0.001 & $-0.015^{* * *}$ & $-0.008^{* * *}$ & $-0.015^{* * *}$ & $-0.009^{* * *}$ \\
\hline & $(0.003)$ & $(0.002)$ & $(0.003)$ & $(0.002)$ & $(0.002)$ & $(0.002)$ & $(0.002)$ & $(0.002)$ \\
\hline \multirow[t]{2}{*}{ Tenant } & -0.003 & -0.002 & -0.008 & -0.005 & -0.008 & -0.011 & -0.013 & $-0.014^{*}$ \\
\hline & $(0.011)$ & $(0.010)$ & $(0.011)$ & $(0.010)$ & $(0.008)$ & $(0.007)$ & $(0.008)$ & $(0.007)$ \\
\hline \multirow[t]{2}{*}{$\begin{array}{l}\text { Subsidized housing (rent- } \\
\text { free) }\end{array}$} & $0.142^{* * *}$ & $0.062^{* * *}$ & $0.138^{* * *}$ & $0.060^{* * *}$ & $0.063 * * *$ & $0.036^{* * *}$ & $0.059 * * *$ & $0.034^{* * *}$ \\
\hline & $(0.022)$ & $(0.011)$ & $(0.022)$ & $(0.011)$ & $(0.012)$ & $(0.007)$ & $(0.012)$ & $(0.007)$ \\
\hline \multicolumn{9}{|l|}{ Averages of time variant vars. } \\
\hline \multirow[t]{2}{*}{$\begin{array}{l}\text { Head - health-related } \\
\text { limitations past } 6 \text { months }\end{array}$} & & & $0.055^{*}$ & $0.036^{*}$ & & & $0.045^{* * *}$ & $0.027^{*}$ \\
\hline & & & $(0.021)$ & $(0.017)$ & & & $(0.014)$ & $(0.011)$ \\
\hline \multirow[t]{2}{*}{$\begin{array}{l}\text { Household - difficulty in loan } \\
\text { payments }\end{array}$} & & & 0.021 & 0.016 & & & -0.008 & -0.000 \\
\hline & & & $(0.022)$ & $(0.017)$ & & & $(0.015)$ & $(0.012)$ \\
\hline \multirow[t]{2}{*}{$\begin{array}{l}\text { Household unable to make } \\
\text { ends meet }\end{array}$} & & & $0.063^{* *}$ & $0.047^{* *}$ & & & $0.117^{* * * *}$ & $0.063^{* * *}$ \\
\hline & & & $(0.024)$ & $(0.018)$ & & & $(0.018)$ & $(0.014)$ \\
\hline \multirow[t]{2}{*}{ sigma u } & 1.574 & 0.002 & 1.580 & 0.002 & 1.545 & 0.001 & 1.548 & 0.001 \\
\hline & $(0.066)$ & $(0.013)$ & $(0.100)$ & $(0.067)$ & $(0.049)$ & $(0.006)$ & $(0.050)$ & $(0.007)$ \\
\hline \multirow[t]{2}{*}{ rho } & 0.712 & 0.000 & 0.714 & 0.000 & 0.705 & 0.000 & 0.706 & 0.000 \\
\hline & $(0.017)$ & $(0.000)$ & $(0.017)$ & $(0.000)$ & $(0.013)$ & $(0.000)$ & $(0.013)$ & $(0.000)$ \\
\hline Observations & 7,854 & 7,854 & 7,854 & 7,854 & 15,144 & 15,144 & 15,144 & 15,144 \\
\hline Number Households & 2,618 & 2,618 & 2,618 & 2,618 & 5,048 & 5,048 & 5,048 & 5,048 \\
\hline
\end{tabular}

Robust standard errors in parentheses, ${ }^{* * *} p<0.001,{ }^{* *} p<0.01,{ }^{*} p<0.05$.

Source: Survey of Income and Living Conditions (2008-11, 2012-15).

The reference period for income variables is the previous year. In order to avoid any inconsistencies, time lag between income variables and household characteristics are adjusted so that we have a three year panel, instead of four years. 
Table 7: Panel Probit Model with Random Effects - Sample with subsidized rents imputed - (Marginal Effects)

\begin{tabular}{|c|c|c|c|c|c|c|c|c|}
\hline \multirow[b]{3}{*}{$\begin{array}{l}\text { Dep. var: Net transfer receiver } \\
\text { (incl. subs. rents) }\end{array}$} & \multicolumn{4}{|c|}{ Panel 2008-2011 } & \multicolumn{4}{|c|}{ Panel 2012-2015 } \\
\hline & RE & RE & CRE & CRE & RE & $\mathrm{RE}$ & CRE & CRE \\
\hline & (a) & (b) & (c) & (d) & (e) & (f) & (g) & (h) \\
\hline \multirow[t]{2}{*}{$\begin{array}{l}\text { Previous year status (net } \\
\text { receiver }=1 \text { ) }\end{array}$} & & $0.395^{* * *}$ & & $0.395^{* * *}$ & & $0.376^{* * *}$ & & $0.374^{* * *}$ \\
\hline & & $(0.004)$ & & $(0.004)$ & & $(0.003)$ & & $(0.003)$ \\
\hline \multirow[t]{2}{*}{ Pre-transfer income (1000 tl) } & $-0.006^{* * *}$ & $-0.003^{* * *}$ & $-0.006^{* * *}$ & $-0.002^{* * *}$ & $-0.005^{* * *}$ & $-0.002^{* * *}$ & $-0.005^{* * *}$ & $-0.002^{* * *}$ \\
\hline & $(0.001)$ & $(0.000)$ & $(0.001)$ & $(0.000)$ & $(0.000)$ & $(0.000)$ & $(0.000)$ & $(0.000)$ \\
\hline \multirow[t]{2}{*}{ Public transfers (individual) } & $-0.010^{* * *}$ & $-0.004^{* * *}$ & $-0.009 * * *$ & $-0.003^{* * *}$ & $-0.009 * * *$ & $-0.003^{* * *}$ & $-0.008^{* * *}$ & $-0.003^{* * *}$ \\
\hline & $(0.001)$ & $(0.001)$ & $(0.001)$ & $(0.001)$ & $(0.001)$ & $(0.000)$ & $(0.001)$ & $(0.000)$ \\
\hline \multirow[t]{2}{*}{ Public transfers (household) } & -0.005 & -0.006 & -0.006 & -0.006 & 0.007 & 0.005 & 0.005 & 0.004 \\
\hline & $(0.008)$ & $(0.005)$ & $(0.008)$ & $(0.005)$ & $(0.005)$ & $(0.003)$ & $(0.004)$ & $(0.003)$ \\
\hline \multirow[t]{2}{*}{ Female household head } & $0.220^{* * *}$ & $0.100^{* * *}$ & $0.212^{* * *}$ & $0.099 * * *$ & $0.174^{* * *}$ & $0.065^{* * *}$ & $0.170^{* * *}$ & $0.064^{* * *}$ \\
\hline & $(0.043)$ & $(0.020)$ & $(0.042)$ & $(0.020)$ & $(0.024)$ & $(0.012)$ & $(0.024)$ & $(0.012)$ \\
\hline \multirow[t]{2}{*}{ Age of household head } & $-0.004^{* * *}$ & -0.000 & $-0.004^{* * *}$ & -0.001 & $-0.004^{* * *}$ & $-0.001^{*}$ & $-0.004^{* * *}$ & $-0.001^{*}$ \\
\hline & $(0.001)$ & $(0.000)$ & $(0.001)$ & $(0.000)$ & $(0.001)$ & $(0.000)$ & $(0.001)$ & $(0.000)$ \\
\hline \multirow[t]{2}{*}{ Primary 5 years } & -0.055 & 0.004 & -0.039 & 0.007 & $-0.090^{* * *}$ & -0.012 & $-0.071^{* *}$ & -0.010 \\
\hline & $(0.033)$ & $(0.012)$ & $(0.031)$ & $(0.011)$ & $(0.025)$ & $(0.008)$ & $(0.023)$ & $(0.008)$ \\
\hline \multirow[t]{2}{*}{ Primary 8 years } & -0.009 & 0.019 & 0.007 & 2 & -0.053 & 0.002 & -0.031 & 0.004 \\
\hline & $(0.046)$ & $(0.016)$ & $(0.044)$ & $(0.016)$ & $(0.034)$ & $(0.011)$ & $(0.032)$ & $(0.011)$ \\
\hline \multirow[t]{2}{*}{ Secondary } & -0.003 & 0.018 & 0.023 & 0.023 & -0.042 & 0.007 & -0.015 & 0.010 \\
\hline & $(0.050)$ & $(0.017)$ & $(0.049)$ & $(0.017)$ & $(0.038)$ & $(0.013)$ & $(0.036)$ & $(0.013)$ \\
\hline \multirow[t]{2}{*}{ Vocational sec. } & 0.079 & 0.032 & 0.099 & $0.036^{*}$ & -0.061 & 0.008 & -0.028 & 0.011 \\
\hline & $(0.062)$ & $(0.019)$ & $(0.060)$ & $(0.019)$ & $(0.037)$ & $(0.013)$ & $(0.035)$ & $(0.013)$ \\
\hline \multirow[t]{2}{*}{ Post-secondary } & -0.038 & 0.032 & -0.006 & $0.037^{*}$ & $-0.110^{* * *}$ & 0.001 & $-0.070^{*}$ & 0.005 \\
\hline & $(0.047)$ & $(0.019)$ & $(0.048)$ & (0.019) & $(0.032)$ & $(0.013)$ & $(0.032)$ & $(0.013)$ \\
\hline \multirow[t]{2}{*}{ Social sec. head or spouse } & $-0.049^{* *}$ & -0.011 & $-0.043^{* *}$ & -0.009 & $-0.036^{* *}$ & -0.006 & $-0.028^{*}$ & -0.005 \\
\hline & $(0.017)$ & $(0.008)$ & $(0.016)$ & $(0.008)$ & $(0.012)$ & $(0.006)$ & $(0.011)$ & $(0.006)$ \\
\hline \multirow[t]{2}{*}{ Never married } & $-0.078^{*}$ & $-0.052^{*}$ & -0.075 & $-0.052^{*}$ & -0.031 & -0.014 & -0.033 & -0.014 \\
\hline & $(0.040)$ & $(0.023)$ & $(0.040)$ & $(0.023)$ & $(0.035)$ & $(0.017)$ & $(0.034)$ & $(0.017)$ \\
\hline \multirow[t]{2}{*}{ Spouse died } & $-0.145^{* * *}$ & $-0.123^{* * *}$ & $-0.147^{* * *}$ & $-0.123^{* * *}$ & $-0.086^{* * *}$ & $-0.068^{* * *}$ & $-0.087^{* * *}$ & $-0.068^{* * *}$ \\
\hline & $(0.017)$ & $(0.018)$ & $(0.017)$ & $(0.018)$ & $(0.016)$ & $(0.012)$ & $(0.016)$ & $(0.012)$ \\
\hline \multirow[t]{2}{*}{ Divorced } & -0.018 & $-0.059^{*}$ & -0.035 & $-0.064^{*}$ & 0.063 & -0.027 & 0.043 & -0.029 \\
\hline & $(0.063)$ & $(0.026)$ & $(0.058)$ & $(0.025)$ & $(0.043)$ & $(0.015)$ & $(0.039)$ & $(0.015)$ \\
\hline \multirow[t]{2}{*}{$\begin{array}{l}\text { Head - health-related } \\
\text { limitations past } 6 \text { months }\end{array}$} & 0.011 & 0.002 & 0.002 & -0.007 & $0.019^{*}$ & $0.013^{*}$ & 0.004 & 0.001 \\
\hline & $(0.013)$ & $(0.008)$ & $(0.014)$ & $(0.011)$ & $(0.009)$ & $(0.006)$ & $(0.009)$ & $(0.008)$ \\
\hline \multirow[t]{2}{*}{$\begin{array}{l}\text { Household - difficulty in loan } \\
\text { payments }\end{array}$} & $-0.028^{*}$ & $-0.018^{*}$ & $-0.033^{*}$ & $-0.024^{*}$ & -0.008 & -0.010 & -0.018 & $-0.021 * *$ \\
\hline & $(0.013)$ & $(0.009)$ & $(0.014)$ & $(0.011)$ & $(0.009)$ & $(0.006)$ & $(0.009)$ & $(0.008)$ \\
\hline \multirow[t]{2}{*}{ One person household } & 0.083 & $0.044^{*}$ & 0.088 & $0.047^{*}$ & $0.054^{*}$ & $0.044^{* * *}$ & $0.060^{* *}$ & $0.046^{* * *}$ \\
\hline & $(0.049)$ & $(0.022)$ & $(0.048)$ & $(0.022)$ & $(0.023)$ & $(0.012)$ & $(0.023)$ & $(0.012)$ \\
\hline
\end{tabular}




$\begin{array}{lcccccccc}\begin{array}{l}\text { Households with no } \\ \text { dependent children }\end{array} & 0.037 & 0.006 & 0.034 & 0.004 & 0.072^{* * *} & 0.028^{* * *} & 0.069^{* * *} & 0.028^{* * *} \\ & (0.021) & (0.011) & (0.021) & (0.011) & (0.013) & (0.008) & (0.013) & (0.008) \\ \begin{array}{l}\text { Lone-parent with dependent } \\ \text { children }\end{array} & 0.209^{*} & 0.094^{*} & 0.200^{*} & 0.091^{*} & 0.141^{* *} & 0.091^{* * *} & 0.134^{* *} & 0.091^{* * *} \\ & (0.093) & (0.038) & (0.089) & (0.038) & (0.047) & (0.023) & (0.045) & (0.023) \\ \text { Household unable to make } & & & & & & & & \\ \text { ends meet } & 0.037^{* *} & 0.007 & 0.022 & -0.010 & 0.010 & 0.006 & -0.010 & -0.010 \\ & (0.013) & (0.009) & (0.013) & (0.011) & (0.009) & (0.007) & (0.009) & (0.008) \\ \text { Household size } & -0.016^{* *} & -0.004 & -0.017^{* *} & -0.004 & -0.025^{* * *} & -0.007^{* * *} & -0.027^{* * *} & -0.008^{* * *} \\ & (0.005) & (0.002) & (0.005) & (0.002) & (0.004) & (0.002) & (0.004) & (0.002)\end{array}$

Averages of time variant vars.

Head - health-related limitations

past 6 months

$\begin{array}{cccc}0.050 & 0.017 & 0.080^{* * *} & 0.024^{*} \\ (0.037) & (0.017) & (0.024) & (0.012)\end{array}$

Household - difficulty in loan payments

$\begin{array}{cccc}0.022 & 0.011 & 0.056^{*} & 0.022 \\ (0.039) & (0.017) & (0.027) & (0.012)\end{array}$

Household unable to make ends meet

$0.136^{* *} \quad 0.047^{*}$

$0.206^{* * *} \quad 0.045^{* *}$

$(0.043) \quad(0.018)$

(0.033) (0.015)

sigma u

$\begin{array}{llll}2.462 & 0.001 & 2.476 & 0.001\end{array}$

$\begin{array}{llll}2.422 & 0.001 & 2.436 & 0.001\end{array}$

(0.097) (0.006)

(0.098) 0.006)

(0.069)

(0.005)

(0.069)

(0.005)

rho

$\begin{array}{llll}0.858 & 0.000 & 0.860 & 0.000\end{array}$

0.854

0.000

0.856

0.000

\begin{tabular}{lccccccccc} 
& $(0.010)$ & $(0.000)$ & $(0.010)$ & $(0.000)$ & $(0.007)$ & $(0.000)$ & $(0.007)$ & $(0.000)$ \\
\hline Observations & 7,854 & 7,854 & 7,854 & 7,854 & 15,144 & 15,144 & 15,144 & 15,144 \\
Number Households & 2,618 & 2,618 & 2,618 & 2,618 & 5,048 & 5,048 & 5,048 & 5,048 \\
\hline
\end{tabular}

Robust standard errors in parentheses, ${ }^{* * *} p<0.001,{ }^{* *} p<0.01,{ }^{*} p<0.05$.

Source: Survey of Income and Living Conditions (2008-11, 2012-15).

The reference period for income variables is the previous year. In order to avoid any inconsistencies, time lag between income variables and household characteristics are adjusted so that we have a three year panel, instead of four years.

Omitted categories for household head are; less than 5 year primary for education level, being married for marital status. In case dwelling dummies, being the owner is reference category. Households with dependent children is the omitted category.

All monetary variables are expressed in 1,000 TL and inflated to 2014 prices.

Broad definition of private transfers include imputed rents if the household receives rent-free subsidized housing.

To get a more accurate understanding of how public and private transfers interact, we report public and private transfers as a percentage of disposable income ${ }^{10}$ by income percentiles (Figure 2, top and middle panels). Strikingly, the top panel of Figure 2 shows that the share of individual public transfers in disposable income exhibits an inverse $U$ shape across percentiles. This relationship typically reflects limited welfare provision in Turkey because individual public transfers are mainly employment-related benefits like retirement pensions. Lower segments receive lower individual public transfers since rural workers are mostly uninsured. The middle panel of Figure 2, however, indicates that the share of public transfers targeted to households decreases with income, becoming almost flat for higher income households. When we compare two periods, we observe that while the share of household public transfers remains unchanged, poorer individual public transfer receivers seem to benefit more from redistribution. This shift might partly be explained in terms of increased social coverage, although it is hard to tell whether the size of transfers increased or the transfer base was extended. Besides policy preferences, it is probable that welfare provision improved in the second period, since the younger generation becomes more urbanized and includes more wage earners than rural agricultural workers. 

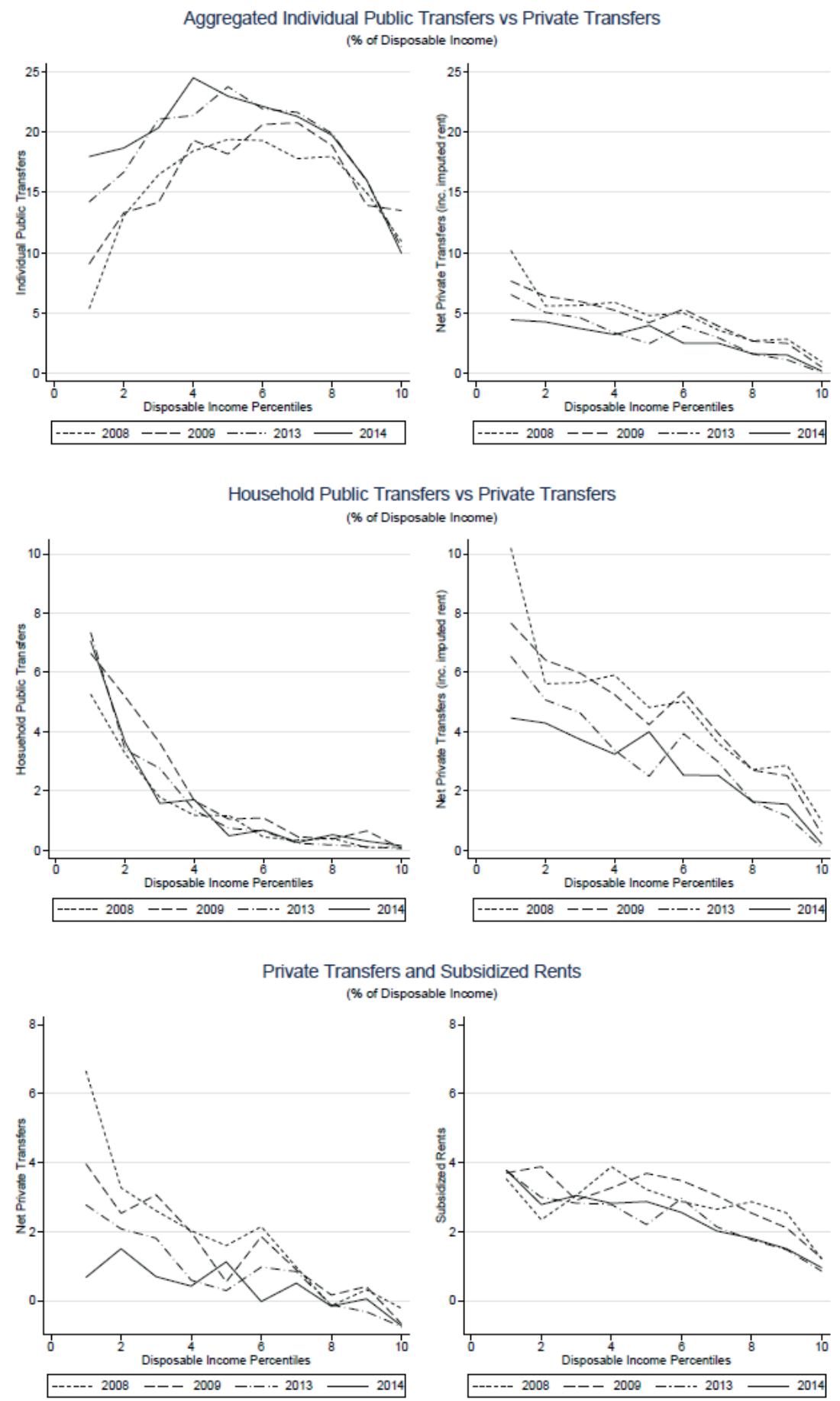

- Source: SILC (2008-11, 2012-15).

- Disposable income is calculated using the OECD equivalence scale. The distribution is weighted with household size.

- The reference period for income variables is the previous year. In order to avoid any inconsistencies, time lag between income variables and household characteristics are adjusted so that we have a three year panel, instead of four years.

Figure 2: Interaction between public and private transfers by disposable income percentiles

The right sides of the top and middle panels show that the share of broadly defined private transfers decline with income, which implies the altruistic be- havior detected in the models. ${ }^{11}$ The downward shift in altruistic behavior over time is remarkable, particularly for lower income segments. It seems that increasing 
public transfers has depressed private transfers for the poorer segments. Note that it is not only the levels but also the differences that suggest further crowding out. Certainly, we need a different estimation strategy to detect this kind of individual effect.

The bottom panel of Figure 2 visualizes our distinction between the narrow and broad definitions of private transfers. ${ }^{12}$ The share of private transfers including housing support (broader definition) is flatter than that of narrowly defined private transfers and hardly changes over time. However, narrowly defined private transfers (the left side of the bottom panel) declines rather drastically over time for the lower segments. Thus, the total variation clearly comes from the narrow definition. It is noteworthy that the share of private transfers (narrowly defined) becomes almost negligible and declines below 2 percent in 2014. Another important observation is that it becomes smoother across income percentiles. Thus, we can assume that housing support is a form of private transfers equally common among higher income households.

Lastly, we could derive some social policy implications related to our findings. First, public transfers at the household level are not extensive. This type of public transfer should be more diversified to include more housing and family support. It is particularly significant for poor single-earner families with children. Latest Covid experience imply that facing a widespread income shock, informal safety nets and private provision have limited capacity to cope with crises (McConnell, 2021). Secondly, transformation of family ties and demographic change imply that private solidarity should be complemented with more broad social transfers like universal basic income.

\section{CONCLUSION}

Inter-household transfers among households can have counter-acting (neutralizing) effects on income redistribution when we consider their interactions with the welfare regime. Public policy should therefore take into account how much public transfers crowd out private ones and make them less effective in alleviating poverty. Using two recent SILC panels for 2009-2011 and 2012-2015, we investigated how the interaction of these transfers has evolved in Turkey. We used two different econometric models to measure the parameters of being a private transfer receiver. In contrast to previous studies of some developed countries, our findings indicate that donors are altruistically rather than exchange motivated. Our results are quite robust for different specifications. The altruistic motive was weaker in 2012-2015 than 2008-2011. We then modified our dependent variable by including subsidized rent in private transfers. The results from this broader definition of private transfers suggest there are downstream transfers from probably wealthier parents to children in Turkey. While the age of the receiver was insignificant in the narrower model, households with younger heads receive more private transfers when private housing support is added to the definition. Our findings indicate that the crowding out effect is only effective through individual public transfers; household-level public transfers do not significantly reduce private transfers. Our findings also highlight the low level of household level public transfers, which may be due to Turkey's ungenerous welfare regime. A related key finding of our study is that private transfers also provide informal safety net for uninsured households.

Consistent with recent demographic trends in Turkey, our results also indicate that female-headed households and households with more educated heads receive more private transfers. Indebtedness had no significant impact on receiving more transfers; on the contrary, in some specifications, households who reported no debt issues receive more transfers. We believe that it is crucial for future research to identify donor households to provide a complete picture of broader private transfer motivations. In its current framework, the SILC data used in this paper is insufficient for investigating particularities of public transfer targeting procedures and eligibility criteria. The time span of public and private transfers is also crucial for further identification issues. A dataset with a longer panel that includes donor information would better detect the dependency of households on transfers in general.

\section{Acknowledgement:}

This research has received financial support from Galatasaray University. The authors gratefully acknowledge the support of Galatasaray University Research Fund (project no:17.103.004) The authors offer special thanks to French Embassy. Selin Pelek hosted by Université Paris-Est Marne-la -Vallée with the research fellowship of French Embassy International Mobility Program while this research was being initiated. 


\section{REFERENCES}

Akarçay-Gürbüz, A. and Polat, S. (2017). Schooling opportunities and intergenerational educational mobility in turkey: An iv estimation using census data. The Journal of Development Studies, 53(9):1396-1413.

Albarran, P. and Attanasio, O. (2002). Do public transfers crowd out private transfers? evidence from a randomized experiment in mexico. WIDER Working Paper Series 006, World Institute for Development Economic Research (UNU-WIDER).

Amuedo-Dorantes, C. and Juarez, L. (2015). Old-age government transfers and the crowding out of private gifts: The 70 and above program for the rural elderly in $m$ exico. Southern Economic Journal, 81(3):782-802.

Arrondel, L., and Masson, A. (2006). Altruism, exchange or indirect reciprocity: what do the data on family transfers show? Handbook of the economics of giving, altruism and reciprocity, 2, 971-1053.

Attias-Donfut, C. and Wolff, F.-C. (2000). Complementarity between private and public transfers. The Myth of Generational Conflict, London und New York, pages 47-68.

Aybars, A. I., \& Tsarouhas, D. (2010). Straddling two continents: Social policy and welfare politics in Turkey. Social Policy \& Administration, 44(6), 746-763.

Barro, R. J. (1974). Are government bonds net wealth? Journal of politicaleconomy, 82(6):1095-1117.

Baslevent, C. (2014). Social transfers and income inequality in turkey: How informative is the survey of income and living conditions? Ekonomi-tek-International Economics Journal, 3(3):23-42.

Becker, G. S. (1974). A theory of social interactions. Journal of political economy, 82(6):1063-1093.

Bernheim, B. D., Shleifer, A., and Summers, L. H. (1985). The strategic bequest motive. Journal of Political economy, 93(6):1045-1076.

Buğra, A. and Adar, S. (2008). Social policy change in countries without mature welfare states: The case of turkey. New Perspectives on Turkey, 38:83-106.

Buğra, A. and Candas, A. (2011). Change and continuity under an eclectic social security regime: The case of turkey. Middle Eastern Studies, 47(3):515-528.

Buğra, A. and Keyder, Ç. (2006). The turkish welfare regime in transformation. Journal of European social policy, 16(3):211228.

Chamberlain, G. (1984). Panel data. Handbook of econometrics, 2:1247-1318.

Cox, D. (1987). Motives for private income transfers. Journal of political economy, 95(3):508-546.

Cox, D., Eser, Z., and Jimenez, E. (1998). Motives for private transfers over the life cycle: An analytical framework and evidence for peru. Journal of Development Economics, 55(1):57-80.
Cox, D., Galasso, E., and Jimenez, E. (2006). Private transfers in a cross section of developing countries. Center for Retirement Research Working Papers, page 111.

Cox, D., Hansen, B. E., and Jimenez, E. (2004). How responsive are private transfers to income? evidence from a laissez-faire economy. Journal of Public Economics, 88(9):2193-2219.

Cox, D. and Jakubson, G. (1995). The connection between public transfers and private interfamily transfers. Journal of Public Economics, 57(1):129-167.

Cox, D. and Jimenez, E. (1990). Achieving social objectives through private transfers: A review. The World Bank Research Observer, 5(2):205-218.

Cox, D. and Jimenez, E. (1992). Social security and private transfers in developing countries: The case of peru. The World BankEconomic Review, 6(1):155-169.

Cox, D. and Rank, M. R. (1992). Inter-vivos transfers and intergenerational exchange. The review of economics and statistics, pages 305-314.

Ezemenari, K. (1997). The link between public and private interhousehold transfers: Implications for the design of safety net programs in developing countries. American Journal of Agricultural Economics, 79(2):666-671.

Fan, E. (2010). Who benefits from public old age pensions? evidence from a targeted program. Economic Development and Cultural Change, 58(2):297-322.

Ferrera, M. (1996). The southern model of welfare in social europe. Journal of European social policy, 6(1):17-37.

Gerardi, K. and Tsai, Y. (2014). The effect of social entitlement programmes on private transfers: New evidence of crowding out. Economica, 81(324):721-746.

Gough, I. (1996). Social assistance in southern europe. South European Society \& Politics, 1(1):1-23.

Grütjen, D. (2007). Social Security in Turkey An Example of the Southern Model?. The role of state, market, and the family in welfare provision, Netzwrk Türkei Working Paper, No:1

Holzmann, R., Hinz, R. P., \& Dorfman, M. (2008). Pension systems and reform conceptual framework. World Bank Discussion Paper, 824.

Holzmann, R. \& Hinz, R. (2005). Old-age income support in the 21st century: An international perspective on pension systems and reform. Washington DC:World Bank Publications.

lacovou, M., Kaminska, O., and Levy, H. (2012). Using eu-silc data for cross-national analysis: strengths, problems and recommendations. Technical report, ISER working paper series.

Jensen, R. T. (2004). Do private transfers 'displace' the benefits of public transfers? evidence from south africa. Journal of Public Economics, 88(1):89-112.

Juarez, L. (2009). Crowding out of private support to the elderly: Evidence from a demogrant in mexico. Journal of Public Economics, 93(3):454-463. 
Jung, H., Pirog, M., and Lee, S. K. (2016). Do public pensions crowd out private transfers to the elderly?: evidence from south korea. Journal of Pension Economics \& Finance, 15(4):455-477.

Kananurak, P. and Sirisankanan, A. (2016). Do public transfers crowd-out private transfers? evidence from the thai socio-economic panel survey. Applied Economics Journal, 23(2):29-47.

Kang, S. J. (2004). Are private transfers crowded out by public transfers? the case of nepal. The Developing Economies, 42(4):510-528.

Kang, S. J. and Lee, M.-j. (2003). Analysis of private transfers with panel fixed-effect censored model estimator. Economics Letters, 80(2):233-237.

Kaufmann, D. and Lindauer, D. L. (1986). A model of income transfers for the urban poor. Journal of Development Economics, 22(2):337-350.

Kaya, E. (2010). Yoksullukla mücadelede avrupa'nın ve türkiye'nin sosyal yardım modeli (1. basım). Ankara:BaĢbakanlık SYDGM Yayınları.

Kim, J. W. and Choi, Y. J. (2011). Does family still matter? public and private transfers in emerging welfare state systems in a comparative perspective. International Journal of Social Welfare, 20(4):353-366.

Kunemund, H. and Rein, M. (1999). There is more to receiving than needing: theoretical arguments and empirical explorations of crowding in and crowding out. Ageing and society, 19(01):93-121.

Laferrère, A. and Wolff, F.-C. (2006). Microeconomic models of family transfers. Handbook of the economics of giving, altruism and reciprocity, 2:889-969.

Maitra, P. and Ray, R. (2003). The effect of transfers on household expenditure patterns and poverty in south africa. Journal of developmentEconomics, 71(1):23-49.
McConnell, K., Merdjanoff, A., Burow, P. B., Mueller, T., \& Farrell, J. (2021). Rural Safety Net Use During the Covid-19 Pandemic. SocArXiv, [Doi]

McKernan, S.-M., Moskowitz, D., and Pitt, M. M. (2005). Use of the formal and informal financial sectors: does gender matter? Empirical evidence from rural Bangladesh. The World Bank.

Nikolov, P. and Adelman, A. (2019). Do private household transfers to the elderly respond to public pension benefits? evidence from rural china. The Journal of the Economics of Ageing, 14:100204.

Nikolov, P. and Bonci, M. (2020). Do public program benefits crowd out private transfers in developing countries? a critical review of recent evidence. A Critical Review of Recent Evidence. IZA Discussion Paper, -(13081).

Pinarcioglu, M. M. and Isik, O. (2009). Segregation in istanbul: Patterns and processes. Tijdschrift voor economische en sociale geografie, 100(4):469-484.

Reil-Held, A. (2006). Crowding out or crowding in? public and private transfers in germany. European Journal of Population/Revue europeenne de Demographie, 22(3):263-280.

Schoeni, R. F. (1997). Private interhousehold transfers of money and time: New empirical evidence. Review of Income and Wealth, 43(4):423-448.

Subbarao, K., Bonnerjee, A., Braithwaite, J., Carvalho, S., Ezemenari, K., Graham, C., and Thompson, A. (1997). Safety net programs and poverty reduction: Lessons from cross-country experience. The World Bank.

Tekgüç, H. (2018). Declining poverty and inequality in turkey: the effect of social assistance and home ownership. South European Society and Politics, 23(4):547-570.

Wooldridge, J. M. (2010). Econometric analysis of cross section and panel data. MIT press.

Wooldridge, J. M. (2016). Introductory econometrics: A modern approach. Nelson Education. 


\section{Endnotes}

1 However, Holzmann and Hinz (2005) draw attention to the unreliable nature of this kind of supports in the face of unexpected shocks such as pandemic. Their multipillar model of pension system takes the housing support into consideration as we do in this paper. We are indebted to an anonymous referee for this point.

2 Note that family and housing transfers are quite low compared to OECD countries. The database is available at https://www.oecd.org/ social/expenditure.html

3 The survey design is compatible with the standard EuroStat SILC.

4 Turkstat uses a rotational design methodology, which allows following up a sub-sample for up to four years. Four sub-samples are surveyed in each year, and from one year to the next, with the oldest sub-sample being replaced with a new one. The sample overlap is $75 \%$ between two consecutive years; $50 \%$ from year $t$ to $t+2 ; 25 \%$ from year $t$ to year $t+3$; and zero for longer periods.

5 All compulsory or voluntary alimony and child support are included. The definition of EuroStat excludes any gifts and other large, one-time or unexpected cash flows or subsidized housing in the form of imputed rents.

6 For the tobit model, we restricted the amount of net donor to take the value of 0 . Thus, this is a left-censored tobit model.

7 Turkey's social security system is based on first degree kinship.

8 One way to remove endogeneity is to use lagged values of pre-transfer income in a two-stage least-squares estimator (2SLS) setting. This is used when more than one exogenous variable is available, i.e. the instrument excluded from the structural model and correlated with an endogenous explanatory variable (Wooldridge (2016). The 2SLS estimator can be obtained in two stages. First, a regression is run to obtain the estimated values of the endogenous variable on the exogenous variables excluded from the structural model. Second, an OLS regression is run using the estimated values of the endogenous variable. Because the estimated version of the endogenous variable is uncorrelated with the error term, the OLS yields consistent estimates. However, this strategy suffers from three major shortcomings in our case. Firstly, private transfers could also be conditioned by past income levels, making the time span inappropriate for the information structure. In this case, the lagged values of pre-transfer income will be correlated with current private transfers, thereby ruling out the use of the IV procedure. Secondly, private transfers may compensate for reduced consumption in households that experience a temporary idiosyncratic shock. Thus, using past income as an IV would inappropriate for predicting current income. Thirdly, donor income could be more strongly correlated with private transfers than the receiving household's pre-transfer income. However, the lack of matched data combining donor and receiver information makes it difficult to overcome the bias emerging from unobserved donor information.

9 For the sake of brevity, we only discuss the results obtained by the tobit regression. Tables 6 and 7 in the technical appendix report the marginal effects for the probit models. Overall, the results obtained by the two different models are consistent and mutually confirming, although there are few exceptions. In particular, household head education level is less significant in the binary case, where level effects do not matter. As we argued before, missing information on the type of receiver (omitted variable bias) could overestimate the effect through dependency. It seems that both the CRE and dynamic panel models (in which the lagged state variable for receiving private transfers are included) improve the model by moderating the effects of our basic predictors, public transfers and pre-transfer income. If the lagged dependent variable is not controlled for in the regressions, we estimate higher coefficients for each key variable.

10 Disposable income is calculated using the OECD equivalence scale. The distribution is weighted by household size.

11 The scales of Figure 2 are modified according to individual and household transfers.

12 We do not restrict net private transfers to have only positive values, which was the case in the model estimations. Negative values at higher percentiles imply the net donation share in terms of disposable income. 